\title{
Financial Integration and the Wealth Effect of Exchange Rate Fluctuations.
}

\author{
Cédric Tille \\ Federal Reserve Bank of New York * \\ First Draft: April 16, 2004 \\ This Draft: August 20, 2004
}

\begin{abstract}
A striking development of the U.S. economy in the 1990s has been the large impact of exchange rate movements on the U.S. international position. Because of the substantial leverage in the U.S. position, with U.S. investors short in dollar securities and long in foreign securities, a depreciation of the dollar leads to a large capital gain for the U.S. We show that this effect is concentrated for movements against European currencies, as Asian currencies make only a small share of the foreign currency securities held by U.S. investors. We incorporate this valuation channel in a simple general equilibrium model, and analyze the international transmission of monetary shocks. We find that the valuation effect of exchange rate movements is a major dimension, dwarfing the usual effects through the trade balance. In addition, the valuation effect of exchange rate movements on welfare operates even when prices are fully flexible.
\end{abstract}

JEL classification: F31, F41, F42

Keywords: foreign assets, valuation effect, exchange rate

\section{PRELIMINARY AND INCOMPLETE}

*Email: cedric.tille@ny.frb.org. I thank Roberto Chang, Philip Lane, Paolo Pesenti, and audience at the Federal Reserve Bank of New York for comments. I also thank Svenja Gudell for providing research assistance. The views in this paper are those of the author and do not necessarily reflect the position of the Federal reserve Bank of New York or the Federal Reserve System. 


\section{Introduction}

A central development of the U.S. economy in recent year is the sharp increase of its indebtness vis-a-vis the rest of the world, with the U.S. net international debt reaching 24 percent of GDP at the end of 2004 (Abaroa 2004). Furthermore, the movements in the net U.S. debt show a substantial volatility since the mid-1990s. In particular, the fluctuations of the dollar exchange rate has led to substantial movements in the value of the U.S. net international investment position (hereinafter NIIP), as documented by Tille (2003). With U.S. liabilities denominated in dollars and a substantial amount of U.S. assets denominated in foreign currency, a depreciation of the dollar boosts the dollar value of U.S. assets and improves the NIIP. In 2003 alone, this valuation effect of the weak dollar offset three-quarters of the U.S. current account deficit (Abaroa 2004).

The presence of large valuation effect from exchange rate movements is receiving a growing amount of attention from researchers. Lane and MilesiFerretti $(2004,2003)$ document the pattern of valuation effects across several counties, while Gourinchas and Rey (2004) look at the performance of the asset positions in forecasting exchange rate movements.

This paper consists of two parts. We first present a detailed breakdown of the composition of the U.S. assets and liabilities across several currencies. We show that the U.S. international portfolio is highly leveraged, with the net debt of 24 percent of GDP at the end of 2003 reflecting a substantial short position in dollars (66 percent of GDP), offset by a large long position in foreign currencies (42 percent of GDP). European currencies constitute the bulk of the foreign currency assets, with the euro, pound and Swiss franc accounting for half the value of assets, while Asian currencies play a much smaller role. The weight of European currencies is well above the importance of the corresponding countries as U.S. trading partners. This pattern indicates that the relative importance of the various channels through which a movement in the exchange rate affects the economy are different depending on which currency the dollar moves against. While a movement against European currencies is liekly to generate a substantial valuation effect, this is not the case for a movement against Asian currencies where the usual impact through the trade balance is likely to dominate.

In the second part of the paper, we incorporate the valuation effect of exchange rate movement in a simple standard open economy model, building on the work by Obstfeld and Rogoff (1995). The setup includes imperfec- 
tions, namely imperfect competitions and price rigidities, that let monetary shocks affect real variables. A particularly useful feature is the presence of a well grounded welfare metric, namely the utility of representative agents in different countries, with which we can evaluate the consequences of monetary shocks. At first, their setup may appear ill-suited to analyze the impact of exchange rate fluctuations on the value of foreign assets. This is because the model is solved in terms of linear approximations around a steady state where no country hold any assets on the other. We show however that the model is less restrictive than it appears: while we require each country to hold no net foreign assets in the steady state around which we approximate the model, there is no restriction on the holdings of gross assets and liabilities. We assume that households in both countries can trade two riskless bonds, one denominated in home currency and the other denominated in foreign currency. It is then possible to consider a situation of leverage across currencies such as the one observed for the U.S., with a country being a debtor in bonds denominated in its own currency, and a creditor in bonds denominated in the foreign currency, with the two positions exactly offsetting each other.

Allowing for non-zero gross positions in the steady state substantially affects the impact of monetary shocks. With non-zero gross positions in different currencies, exchange rate movements lead to a valuation effect that is a pure wealth transfer across countries. We find that its impact on welfare is substantial. Under a calibration reflecting the current situation of the U.S., the benefit for a country following a monetary expansion is 6 times as big as when gross assets and liabilities are zero, as in Obstfeld and Rogoff (1995). Furthermore, the valuation effect of exchange rate movements does not hinge on price rigidities, the welfare effect being of similar magnitude when good prices are fully flexible. Introducing non-traded goods in the model leaves our conclusion unaffected.

The paper is organized as follows. Section 2 reviews the impact of exchange rate movements on the values of the U.S. foreign assets and liabilities in the 1990s, and presents a detailed analys of the currency composition of the U.S. portfolio. Section 3 derives a micro-founded general equilibrium model with valuation effects, building on the contributions by Obstfeld and Rogoff (1995) and Hau (2000). As the setup is standard along many dimensions, we focus on the novel aspects and leave the detailed exposition in the Appendix. Section 4 derives the solution of the model and illustrates the results through a simple numerical example. Section 5 concludes. 


\section{The leveraged investment position of the U.S.}

\subsection{Exchange rate movements as a driver of the U.S. balance sheet}

Over the last 20 years, the United States have moved from being a net creditor vis-a-vis the rest of the world to a net debtor, with the movements in the net U.S. debt showin substantial volatility since the mid-1990s. Figure 1 shows the NIIP of the U.S., computed by the Bureau of Economic Analysis from the end of 1982 to the end of 2003 (Abaroa 2004). The NIIP is defined as the difference between foreign assets held by U.S. investors and U.S. liabilities to foreign investors. The figures are shown both in billions of dollars (dotted line) and as a percentage of GDP (solid line). The evolution of the NIIP went through three distinct stages. Between 1982 and 1996 the U.S. gradually moved from a net creditor to a net debtor position, with the NIIP moving from +7 to -5 percent of GDP. The pace of debt accumulation then substantially picked up in the second half of the 1990s, with the NIIP reaching - 23 percent of GDP by the end of 2001. The foreign indebtedness of the U.S. has stabilized in the last two years, with the NIIP only marginally worsening to - 24 percent of GDP at the end of 2003.

The stabilization of the NIIP over the last two years appears puzzling at first, as we would expected the substantial current account deficits, averaging $5.5 \%$ of GDP annually in 2002-2003, to have pushed the U.S. much further into debt. We shed light on this apparent discrepancy by reviewing the three factors that drive the NIIP, as discussed in Tille (2003):

- Financial flows: the value of U.S. assets increases when U.S. investors purchase additional foreign securities, with new purchases of U.S. securities by foreign investors boosting U.S. liabilities. The difference between these flows corresponds to the current account balance.

- Securities prices: the value of the U.S. holdings of foreign securities increases with gains in foreign stock markets, and conversely the value of foreign holdings moves with the U.S. stock market.

- Exchange rate: the dollar value of securities denominated in foreign currencies decreases when the dollar appreciates. Because the amount 
of U.S. assets denominated in foreign currencies exceeds the amount of U.S. liabilities denominated in foreign currencies, as detailed below, an appreciation of the dollar worsens the NIIP.

The evolution of the U.S. NIIP between 1996 and 2003 is illustrated in table 1 , which presents the average annual changes in the NIIP, along with the amounts reflecting financial flows, movements in security prices and exchange rate fluctuations. The table also indicates the changes in the external value of the dollar against the U.S. 17 major trading partners, with a negative number indicating a depreciation of the dollar. The main message is that the impact of exchange rate movements on the U.S. NIIP is substantial, and has been growing throught the sample. Until 2001, the appreciation of the dollar re-inforced the current account deficit in driving the U.S. into debt. By contrast, the depreciation of the dollar over the last two years has boosted the value of U.S. holdings overseas denominated in foreign currencies, thereby stabilizing the U.S. debt. The magnitude of the effect is substantial, offseting three quarters of the current account deficit in 2003 alone.

Not only have exchange rate movements becomes a major driver of the U.S. NIIP, but their impact is concetnrated nearly exclusively on U.S. gross assets. Figure 2, which shows the valuation effect for both gross U.S. assets and liabilities since 1990, expressed as percentage of GDP. ${ }^{1}$ It clearly shows the large and growing magnitude of the valuation effect, with the net effect amounting to 3.8 percent in 2003, as well as its concentration on the asset side of the balance sheet, with little impact on liabilities.

Because the exchange rate valuation effect is concentrated on the U.S. gross assets, a given movement in the external value of the dollar can have very different implications for a given NIIP depending on the degree of financial integration. ${ }^{2}$ We define financial integration as the degree to which the U.S. balance sheet is leveraged between gross assets and liabilities. If financial integration is moderate, the U.S. net position is the difference between relatively small amounts of gross assets and liabilities. An exchange rate movement then has only a small valuation effect. By contrast if intergration is substantial, the same net position is the difference between large amounts of gross assets and liabilities, and the same exchange rate movement has a large valuation effect, as it applies to a bigger gross asset position. The

\footnotetext{
${ }^{1}$ The BEA published the decomposition of NIIP changes across exchange rate and security prices movements only since 1990 .

${ }^{2}$ For a simple example illustrating this aspect, see Tille (2003).
} 
degree of financial integration between the U.S. and the rest of the world has indeed increased since the 1990s, explaining the more prominent role of exchange rate valuation effects. Figure 3 presents the gross U.S. assets and liabilities, scaled by GDP. Over the last ten years the value of U.S. assets nearly doubled as a percentage of GDP, with an even larger increase for the value of U.S. liabilities. This rise in integration is not specific to the U.S. and reflects a worldwide pattern, as discussed in Lane and Milesi-Ferretti (2004, 2003).

\subsection{The currency composition of U.S. assets and lia- bilities}

The concentration of the exchange rate valuation effect on U.S. clearly points to a substantial share of foreign currency denominated securities in gross U.S. assets, with a much smaller share in U.S. liabilities. We now take a closer look at the exact size of the positions in foreign currencies, as well as their composition across the various world currencies.

Our analysis relies primarily on the surveys of U.S. FDI assets, and U.S. assets and liabilities in long term securities (BEA 2003, Federal Reserve Bank of New York et al. 2002, 2001). A description of the estimation is provided in the Appendix. ${ }^{3}$

The currency composition of the U.S. gross asset and liability positions at the end of 2003 is presented in table 2. Securities denominated in foreign currencies account for two-thirds of the U.S. gross assets, and more than 90 percent of the assets in FDI, equity and long term debt (hereinafter F-ED). ${ }^{4}$ By contrast to assets, the bulk of U.S. liabilities to foreign investors is denominated in U.S. dollar, with foreign currencies accouting for a mere 5 percent of the total, essentially in European currencies.

These holdings of U.S. assets denominated in foreign currencies are highly concentrated across a few currencies, with the three major European ones (euro, U.K. pound and Swiss franc) accounting for one-third of U.S. gross assets, i.e. one-half of the assets denominated in foreign currencies. While the Japanese yen and Canadian dollar account for a substantial share of U.S. assets (10 percent), their weight remains far below that of European ones.

\footnotetext{
${ }^{3} \mathrm{~A}$ more detailed decomposition is available upon request.

${ }^{4}$ Our computations assume that FDI and equity securities held by U.S. investors in a foreign country are denominated in the local currency.
} 
An interesting aspect is the substantial fraction of U.S. assets invested in Caribbean currencies, which account for 6 percent of all U.S. assets. The extent to which these holdings can be viewed as holdings of foreign assets in foreign currencies is open to question however. Caribbean currencies show very little, if any, movement against the dollar, making any effect of exchange rate movements on the value of U.S. holdings in these countries highly unlikely. ${ }^{5}$

The currency composition of the NIIP is presented in table 3, with the first column indicating the value of the positions in billions of dollar, and the second column showing them relative to the U.S. GDP. In addition to the high leverage between gross assets and liabilities shown in figure 3, the U.S. NIIP shows a substantial degree of leverage across currencies. The net debt of 24 percent of GDP represents the difference between a short position in U.S. dollars and a long position in foreign currencies amounting to 66 and 42 percent GDP, respectively. ${ }^{6}$

The final column of table 3 shows the position in a given foreign currency as a share of the total net positions in all foreign currencies. As for gross assets, European currencies dominate the net U.S. assets in foreign currencies, with the euro, pound and Swiss franc accounting for half the position. By contrast the Japanese yen and the Canadian dollar account for a mere 16 percent of the position, with other Asian currencies adding another 12 percent.

Our analysis shows that movements in the value of the dollar against other currencies can generate substantial valuation effects given the large position held by U.S. investors in securities denominated in foreign currency. Specifically, a 10 percent depreciation of the dollar across the board generates a valuation gain amounting to 4 percent of U.S. GDP. We also find that the magnitude of the gains depends on which currency the dollar moves against, with a depreciation against European currencies generating a more substantial effect than an equal depreciation against Asian currencies.

The large weight of European currencies in the U.S. portfolio goes beyond

\footnotetext{
${ }^{5}$ Between January 1994 and January 2004, the East Caribbean dollar, Aruba guilder, Bahamian dollar, Bermudian dollar, Caymanian dollar, Netherlands Antillean guilder and Trinidad and Tobago dollar moved by $0.4 \%, 0.3 \%, 0 \%, 0 \%, 0.2 \%, 0.7 \%$ and $11.6 \%$, respectively against the U.S. dollar.

${ }^{6}$ If we include the holdings in Caribbean currencies in the holdings in U.S. dollar, the leverage is only moderately reduced, with the short U.S. dollar and long foreign currencies position reaching 62 and 38 percent of GDP.
} 
what can be expected based on trade linkages. Figure 4 shows the share of the various currencies in the U.S. foreign currency NIIP (i.e. the last xolumn of table 3) against the share of the corresponding countries in U.S. exports outside the U.S. dollar zone. The euro, U.K. pound, Swiss francs and Caribbean currencies each make a much larger share of the U.S. portfolio than of U.S. exports. By contrast, Canada, Latin America and non-Japan Asia are under-weighted in the U.S. portfolio relative to their importance as markets for U.S. exports. The weight of the Japanese yen is in line with the role Japan as a U.S. trading partner.

The discrepancy between the weights of various currencies in the U.S. portfolio and the importance of the corresponding countries as U.S. trading partners indicate that the relative importance of the various channels through which exchange rate movements affect the U.S. economy is likely to depend on which currencies the dollar moves against. The first channel through which a movement in the exchange rate operates is the trade channel, with a depreciation of the dollar making U.S. goods more competitive and thereby boosting U.S. exports. The second cahnnel is the valuation channel that is at the center of our analysis, with a depreciation leading to a wealth transfer in favor of the U.S. by boosting the dollar value of U.S. assets denominated in foreign currencies. The geographical pattern depicted in figure 4 indicates that the valuation channel can be expected to play a substantial role when the dollar moves against European currencies. By contrast it should be more muted when the dollar moves against Asian and Latin American currencies, with the impact coming primarily through the trade channel.

\section{A simple model of the impact of exchange rate movements}

\subsection{General structure}

We analyze the impact of exchange rate movements using a simple microfounded general equilibrium model, following Obstfeld and Rogoff (1995). As their setup is by now a workhorse of international economics, we focus on the innovative dimensions of our analysis, with more details being presented in the analysis.

The world is made of two countries, home and foreign, each of size $1 / 2$. Each country is inhabited by a representative household who consumes a 
range of different goods and works in domestic firms she owns. There is a continuous unit range of brands available for consumption, with each country producing half the brands. We allow for the presence of non-traded goods as in Hau (2000), with a fraction $\gamma \in[0,1]$ of brands being nontradable. Specifically, brands on the $[0, \gamma / 2)$ interval are nontradable goods produced in the home country, brands on the $[\gamma / 2,1 / 2)$ interval are tradable goods produced in the home country, brands on the $[1 / 2,1-\gamma / 2)$ interval are tradable goods produced in the foreign country, brands on the $[1-\gamma / 2,1]$ interval are nontradable goods produced in the foreign country.

The model is solved in terms of linear expansions around a steady state where no country holds any net claims on the other, although holdings of gross claims denominated in different currencies are allowed. This allows us to capture the currency leverage that we documented for the U.S. investment position. We use our setup to undertake the standard analysis of the impact of permanent monetary shocks. Two versions of the model are considered: one where goods prices are flexible, and another where firms set their prices one period in advance before observing the shocks.

\subsection{Household's optimization}

\subsubsection{Consumption allocation}

The goal of the home household at time $t$ is to maximize the following intertemporal utility function:

$$
U_{t}=\sum_{s=0}^{\infty} \beta^{s}\left[\ln C_{t+s}+\chi \ln \left(\frac{M_{t+s}}{P_{t+s}}\right)-\kappa H_{t+s}\right]
$$

where $C$ is consumption of a basket detailed below, $M$ are nominal balances, $P$ is the consumer price index, and $H$ is the number of hours worked. The consumption basket consists of traded and non-traded goods:

$C=\left[\left(\frac{1-\gamma}{2-\gamma}\right)^{\frac{1}{\lambda}}\left(C_{H T}\right)^{\frac{\lambda-1}{\lambda}}+\left(\frac{1-\gamma}{2-\gamma}\right)^{\frac{1}{\lambda}}\left(C_{F T}\right)^{\frac{\lambda-1}{\lambda}}+\left(\frac{\gamma}{2-\gamma}\right)^{\frac{1}{\lambda}}\left(C_{N}\right)^{\frac{\lambda-1}{\lambda}}\right]^{\frac{\lambda}{\lambda-1}}$

where $C_{H T}$ is an index of traded goods produced in the home country, $C_{F T}$ is an index of traded goods produced in the foreign country, and $C_{N}$ is an index of non-traded goods produced in the home country. $\lambda$ is the elasticity 
of substitution between the three indexes, each of which consist of various brands indexed by $z$ :

$$
\begin{aligned}
C_{H T} & =\left[\left(\frac{2}{1-\gamma}\right)^{\frac{1}{\theta}} \int_{\gamma / 2}^{1 / 2}\left(C_{H T}(z)\right)^{\frac{\theta-1}{\theta}} d z\right]^{\frac{\theta}{\theta-1}} \\
C_{F T} & =\left[\left(\frac{2}{1-\gamma}\right)^{\frac{1}{\theta}} \int_{1 / 2}^{1-\gamma / 2}\left(C_{F T}(z)\right)^{\frac{\theta-1}{\theta}} d z\right]^{\frac{\theta}{\theta-1}} \\
C_{N} & =\left[\left(\frac{2}{\gamma}\right)^{\frac{1}{\theta}} \int_{0}^{\gamma / 2}\left(C_{N}(z)\right)^{\frac{\theta-1}{\theta}} d z\right]^{\frac{\theta}{\theta-1}}
\end{aligned}
$$

where $\theta>1$ is the elasticity of substitution between two brands. We make the usual assumption that there is more substitutability between brands than between different types of goods: $\theta>\lambda$. The demands for the various brands are computed along usual lines, leading to:

$$
\begin{aligned}
C_{H T}(z) & =\frac{2}{2-\gamma}\left[\frac{P_{H T}(z)}{P_{H T}}\right]^{-\theta}\left[\frac{P_{H T}}{P}\right]^{-\lambda} C \\
C_{F T}(z) & =\frac{2}{2-\gamma}\left[\frac{P_{F T}(z)}{P_{F T}}\right]^{-\theta}\left[\frac{P_{F T}}{P}\right]^{-\lambda} C \\
C_{N}(z) & =\frac{2}{2-\gamma}\left[\frac{P_{N}(z)}{P_{N}}\right]^{-\theta}\left[\frac{P_{N}}{P}\right]^{-\lambda} C
\end{aligned}
$$

where $P_{H T}(z)$ is the price, in home currency, of a unit of a traded brand $z$ produced in the home country. $P_{F T}(z)$ and $P_{N}(z)$ are the corresponding prices for a foreign traded brand and a home non-traded brand respectively. 
$P_{H T}, P_{F T}, P_{N}$ and $P$ are the usual cost-minimizing price indexes. ${ }^{7}$ The consumption allocation of the foreign household is computed along similar lines.

We assume that the law of one price holds for traded goods. Denoting foreign-currency prices with an asterisk, this implies: $P_{F T}(z)=S P_{F T}^{*}(z)$ and $P_{H T}(z)=S P_{H T}^{*}$, where $S$ is the exchange rate, defined as the amount of home currency required to purchase one unit of foreign currency. In equilibrium, all firms in a given sector in a given country set identical prices. We can therefore drop the brand indexes $z$ and write the consumer price indexes in both countries as:

$$
\begin{aligned}
P & =\left[\frac{1-\gamma}{2-\gamma}\left[P_{H T}\right]^{1-\lambda}+\frac{1-\gamma}{2-\gamma}\left[S P_{F T}^{*}\right]^{1-\lambda}+\frac{\gamma}{2-\gamma}\left[P_{N}\right]^{1-\lambda}\right]^{\frac{1}{1-\lambda}} \\
P^{*} & =\left[\frac{1-\gamma}{2-\gamma}\left[\frac{P_{H T}}{S}\right]^{1-\lambda}+\frac{1-\gamma}{2-\gamma}\left[P_{F T}^{*}\right]^{1-\lambda}+\frac{\gamma}{2-\gamma}\left[P_{N}^{*}\right]^{1-\lambda}\right]^{\frac{1}{1-\lambda}}
\end{aligned}
$$

\subsubsection{Intertemporal allocation}

In addition of domestic currency, households can hold two different bonds, one denominated in home currency and one denominated in foreign currency. The budget constraint of the home household for period $t$ is expressed in nominla terms as:

$$
\begin{aligned}
& P_{t} C_{t}+M_{t}+B_{H t+1}+S_{t} B_{F t+1} \\
= & \Pi_{t}+W_{t} H_{t}+T_{t}+M_{t-1}+\left(1+i_{t}\right) B_{H t}+S_{t}\left(1+i_{t}^{*}\right) B_{F t}
\end{aligned}
$$

\footnotetext{
${ }^{7}$ Specifically:

$$
\begin{aligned}
P_{H T} & =\left[\frac{2}{1-\gamma} \int_{\gamma / 2}^{1 / 2}\left[P_{H T}(z)\right]^{1-\theta} d z\right]^{\frac{1}{1-\theta}} \\
P_{F T} & =\left[\frac{2}{1-\gamma} \int_{1 / 2}^{1-\gamma / 2}\left[P_{F T}(z)\right]^{1-\theta} d z\right]^{\frac{1}{1-\theta}} \\
P_{N} & =\left[\frac{2}{\gamma} \int_{0}^{\gamma / 2}\left[P_{N}(z)\right]^{1-\theta} d z\right]^{\frac{1}{1-\theta}} \\
P & =\left[\frac{1-\gamma}{2-\gamma}\left[P_{H T}\right]^{1-\lambda}+\frac{1-\gamma}{2-\gamma}\left[P_{F T}\right]^{1-\lambda}+\frac{\gamma}{2-\gamma}\left[P_{N}\right]^{1-\lambda}\right]^{\frac{1}{1-\lambda}}
\end{aligned}
$$
}


The household allocates her resources between consumption, $P_{t} C_{t}$, nominal balances, $M_{t}$, and bonds. $B_{H t+1}$ and $B_{F t+1}$ are the quantity of home- and foreign-currency bonds, respectively, that she purchases. The value in home currency of her purchase of foreign-currency bonds is computed using the exchange rate $S_{t}$. The resources of the home household consist of the profits of home firms she owns, $\Pi_{t}$, her wage income, $W_{t} H_{t}$, a lump-sum transfer for the government, $T_{t}$, her initial cash balances, $M_{t-1}$, and the gross return on her initial bond holdings. The quantities of home- and foreign-currency bonds that the household holds at the beginning of period $t$ are $B_{H t}$ and $B_{F t}$ respectively. The interest paid on the home-currency bonds is $i_{t}$, while the interest paid on the foreign-currency bonds is $i_{t}^{*}$.

The maximization of (1) subject to (4) leads to the following money demand, labor supply, Euler condition and interest parity relation:

$$
\begin{aligned}
\frac{M_{t}}{P_{t}} & =\chi C_{t} \frac{1+i_{t+1}}{i_{t+1}} \\
W_{t} & =\kappa P_{t} C_{t} \\
C_{t+1} & =\beta C_{t}\left(1+i_{t+1}\right) \frac{P_{t}}{P_{t+1}} \\
\left(1+i_{t+1}\right) & =\left(1+i_{t+1}^{*}\right) \frac{S_{t+1}}{S_{t}}
\end{aligned}
$$

The optimization of the foreign household is similar. Denoting foreign variables with an asterisk, the budget constraint of the foreign household for period $t$ is:

$$
\begin{aligned}
& P_{t}^{*} C_{t}^{*}+M_{t}^{*}+\frac{1}{S_{t}} B_{H t+1}^{*}+B_{F t+1}^{*} \\
= & \Pi_{t}^{*}+W_{t}^{*} H_{t}^{*}+T_{t}^{*}+M_{t-1}^{*}+\frac{1}{S_{t}}\left(1+i_{t}\right) B_{H t}^{*}+\left(1+i_{t}^{*}\right) B_{F t}^{*}
\end{aligned}
$$

where the various variables are defined similarly to their home counterparts in (4). $B_{H t}^{*}$ and $B_{F t}^{*}$ are the quantity of home- and foreign-currency bonds, respectively, that the foreign household holds at the beginning of period $t$. The optimization by the foreign household leads to the following money 
demand, labor supply and Euler condition:

$$
\begin{aligned}
\frac{M_{t}^{*}}{P_{t}^{*}} & =\chi C_{t}^{*} \frac{1+i_{t+1}^{*}}{i_{t+1}^{*}} \\
W_{t}^{*} & =\kappa P_{t}^{*} C_{t}^{*} \\
C_{t+1}^{*} & =\beta C_{t}^{*}\left(1+i_{t+1}^{*}\right) \frac{P_{t}^{*}}{P_{t+1}^{*}}
\end{aligned}
$$

\subsection{Firms' optimization}

Aggregating the consumption allocation rules across the home and foreign households, and using the law of one price, the demands faced by representative home firms in the traded and non-traded sector, respectively, are:

$$
\begin{aligned}
Y_{T}(z) & =\frac{1}{2-\gamma}\left[\frac{P_{H T}(z)}{P_{H T}}\right]^{-\theta}\left[\frac{P_{H T}}{P}\right]^{-\lambda}\left[C+\left[\frac{P}{S P^{*}}\right]^{-\lambda} C^{*}\right] \\
Y_{N}(z) & =\frac{1}{2-\gamma}\left[\frac{P_{N}(z)}{P_{N}}\right]^{-\theta}\left[\frac{P_{N}}{P}\right]^{-\lambda} C
\end{aligned}
$$

Following similar steps for foreign firms we write:

$$
\begin{aligned}
& Y_{T}^{*}(z)=\frac{1}{2-\gamma}\left[\frac{P_{F T}^{*}(z)}{P_{F T}^{*}}\right]^{-\theta}\left[\frac{P_{F T}^{*}}{P^{*}}\right]^{-\lambda}\left[\left[\frac{S P^{*}}{P}\right]^{-\lambda} C+C^{*}\right] \\
& Y_{N}^{*}(z)=\frac{1}{2-\gamma}\left[\frac{P_{N}^{*}(z)}{P_{N}^{*}}\right]^{-\theta}\left[\frac{P_{N}^{*}}{P^{*}}\right]^{-\lambda} C^{*}
\end{aligned}
$$

We consider a simple constant returns to scale technology for all firms, through which one hour worked is converted into one unit of output. Each firm is the unique producer of a particular brand, and therefore has some monopoly power. When firms can set their prices, they choose a markup over the wage reflecting the degree of monopolistic competition:

$$
P_{H T}(z)=P_{N}(z)=\frac{\theta}{\theta-1} W \quad P_{F T}^{*}(z)=P_{N}^{*}(z)=\frac{\theta}{\theta-1} W^{*} \quad \forall z
$$




\subsection{Current accounts}

We abstract from government spending and assume that in both countries seigniorage revenue is repaid to the household through a lump-sum transfer: $T_{t}=M_{t}-M_{t-1}$ and $T_{t}^{*}=M_{t}^{*}-M_{t-1}^{*}$. We also consider that bonds are in zero net supply worldwide:

$$
B_{H t}+B_{H t}^{*}=B_{F t}+B_{F t}^{*}=0
$$

As households own the firms located in their countries, the sum of their dividend and wage income is equal to the sales revenues of all firms:

$$
\begin{aligned}
R E V_{t}= & \Pi_{t}+W_{t} H_{t}=P_{N t} \frac{\gamma}{2-\gamma}\left[\frac{P_{N t}}{P_{t}}\right]^{-\lambda} C_{t} \\
& +P_{H T t} \frac{1-\gamma}{2-\gamma}\left[\frac{P_{H T t}}{P_{t}}\right]^{-\lambda}\left[C_{t}+\left[\frac{P_{t}}{S_{t} P_{t}^{*}}\right]^{-\lambda} C_{t}^{*}\right] \\
R E V_{t}^{*}= & \Pi_{t}^{*}+W_{t}^{*} H_{t}^{*}=P_{N t}^{*} \frac{\gamma}{2-\gamma}\left[\frac{P_{N t}^{*}}{P_{t}^{*}}\right]^{-\lambda} C_{t}^{*} \\
& +P_{F T t}^{*} \frac{1-\gamma}{2-\gamma}\left[\frac{P_{F T t}^{*}}{P_{t}^{*}}\right]^{-\lambda}\left[\left[\frac{S_{t} P_{t}^{*}}{P_{t}}\right]^{-\lambda} C_{t}+C_{t}^{*}\right]
\end{aligned}
$$

Combining these assumptions with the households budget constraints (4) and (9), we write the current account relation for the home country as:

$$
\begin{aligned}
& P_{t} C_{t}+B_{H t+1}+S_{t} B_{F t+1} \\
= & R E V_{t}+\left(1+i_{t}\right) B_{H t}+S_{t}\left(1+i_{t}^{*}\right) B_{F t}
\end{aligned}
$$

Similarly, the foreign current account is:

$$
\begin{aligned}
& P_{t}^{*} C_{t}^{*}-\frac{1}{S_{t}} B_{H t+1}-B_{F t+1} \\
= & R E V_{t}^{*}-\frac{1}{S_{t}}\left(1+i_{t}\right) B_{H t}-\left(1+i_{t}^{*}\right) B_{F t}
\end{aligned}
$$

\subsection{A steady state with non-zero gross asset positions}

While we cannot derive a closed form solution of the model in general, we can do so in the specific case where the two households do not hold any net claims on each other:

$$
B_{H 0}+S_{0} B_{F 0}=0 \quad B_{H 0}^{*}+S_{0} B_{F 0}^{*}=0
$$


In the steady state, the interest rate on all bonds is equal to the discount rate: $\beta\left(1+i_{0}\right)=\beta\left(1+i_{0}^{*}\right)=1$. All real variables are identical in both countries. The aggregate consumption is identical for both households, reflecting the cost of effort and the degree of monopolistic competition:

$$
C_{0}=C_{0}^{*}=\frac{\theta-1}{\kappa \theta}
$$

The consumption of a specific brand by any household is identical, regardless of the country of production and whether the brand is traded or not:

$$
C_{N 0}(z)=C_{H T 0}(z)=C_{F T 0}(z)=C_{N 0}^{*}(z)=C_{H T 0}^{*}(z)=C_{F T 0}^{*}(z)=\frac{2}{2-\gamma} C_{0}
$$

The output of representative firms are:

$$
Y_{T 0}=Y_{T 0}^{*}=\frac{2}{2-\gamma} C_{0} \quad Y_{N 0}=Y_{N 0}^{*}=\frac{1}{2-\gamma} C_{0}
$$

The price and wage differentials across countries reflect the exchange rate, which is simply the ratio of money supplies: $S_{0}=P_{0} / P_{0}^{*}=W_{0} / W_{0}^{*}=$ $M_{0} / M_{0}^{*}$.

The innovation of this paper is to allow for non-zero gross asset positions in the initial steady state. While solving for the steady state requires net asset positions to be zero (23), there is no constraint that the gross positions themselves be zero. From (18) and (23) we can write all gross asset positions as functions of the holdings of home-currency bonds by the home household, $B_{H 0}$ :

$$
B_{F 0}=-\frac{1}{S_{0}} B_{H 0} \quad B_{H 0}^{*}=-B_{H 0} \quad B_{F 0}^{*}=\frac{1}{S_{0}} B_{H 0}
$$

While the usual approach of existing contributions is to set all gross positions to be zero (i.e. $B_{H 0}=0$ ), this is not necessary. The steady state is still defined if for instance the home household holds a short position in home currency bonds that is exactly offset by a long position in foreign currency bonds, in which case $B_{H 0}<0$. This position is mirrored by the foreign household.

For convenience, we define the ratio between the home household position in home-currency bonds and steady state GDP as:

$$
b_{H 0}=\frac{B_{H 0}}{P_{0} C_{0}}
$$


$b_{H 0}<0$ implies that in the initial steady state both households are debtors in bonds denominated in their own currency, which is the situation we documented for the U.S.

\subsection{Linear approximations}

We solve our model by expressing the various relations in terms of linear approximations around the steady-state described above. We denote the logs deviations by San Serif letter: $\mathrm{x}=\ln X-\ln X_{0}=\left(X-X_{0}\right) / X_{0}$. Most relations are standard, and the approximations are presented in the Appendix.

The novel dimension of our model is in the current account relations (21)-(22). The home current account(21) is approximated as:

$$
\mathrm{p}_{t}+\mathrm{c}_{t}+\mathrm{b}_{t+1}=\mathrm{rev}_{t}+\frac{1}{\beta} \mathrm{b}_{t}-\frac{1-\beta}{\beta} b_{H 0} \mathrm{~s}_{t}+\left(d i_{t}-d i_{t}^{*}\right) b_{H 0}
$$

where:

$$
\mathrm{b}_{t}=\frac{B_{H t}+S_{0} B_{F t}}{P_{0} C_{0}}
$$

The left-hand side and the first two terms of the right hand-side of (25) are the usual expressions found in earlier contributions. Consumption spending and the purchase of foreign assets is financed by the revenue of sales and the gross return on the initial portfolio of foreign assets. The last two terms on the right-hand side are novel, and are present only when the gross asset positions in the steady state are not zero $\left(b_{H 0} \neq 0\right)$.

The third term reflects the valuation effect of exchange rate movements. If the home country is a debtor in home-currency bonds and a creditor in foreign-currency bonds $\left(b_{H 0}<0\right)$, a depreciation of the home currency $\left(s_{t}>\right.$ 0 ) generates a favorable wealth transfer as it increases the home currency value of the foreign-currency bonds held by the home household. The fourth term in the right-hand side captures the gains / losses of leveraging across securities earning different returns. If $b_{H 0}<0$ and $d i_{t}>d i_{t}^{*}$, the home household suffers a loss as she pays a higher interest on her debt that she earns on her assets.

The foreign current account (22) is similarly expanded as :

$$
\mathrm{p}_{t}^{*}+\mathrm{c}_{t}^{*}-\mathrm{b}_{t+1}=\operatorname{rev}_{t}^{*}-\frac{1}{\beta} \mathrm{b}_{t}+\frac{1-\beta}{\beta} b_{H 0} \mathrm{~s}_{t}-\left(d i_{t}-d i_{t}^{*}\right) b_{H 0}
$$


Welfare is evaluated by taking approximations of the home utility (1) and its foreign counterpart. We take the usual step of neglecting the direct welfare impact of real balances and focus on the role of consumption and output.

$$
\begin{aligned}
& \mathrm{u}_{t}=U_{t}-U_{0}=\sum_{s=0}^{\infty} \beta^{s}\left[\mathrm{c}_{t+s}-\frac{\theta-1}{\theta} \mathrm{y}_{t+s}\right] \\
& \mathrm{u}_{t}^{*}=U_{t}^{*}-U_{0}=\sum_{s=0}^{\infty} \beta^{s}\left[\mathrm{c}_{t+s}^{*}-\frac{\theta-1}{\theta} \mathrm{y}_{t+s}^{*}\right]
\end{aligned}
$$

\section{The valuation impact of monetary shocks}

\subsection{The key relation}

We use our model to assess the consequences of a permanent monetary shock at time $t: \mathrm{m}_{t}=\overline{\mathrm{m}}$ and $\mathrm{m}_{t}^{*}=\overline{\mathrm{m}}^{*}$. Our analysis focuses on the novel aspects of the model, with the detailed solution presented in the Appendix. The key relation is the current accounts (25)-(26) which are expressed in cross-country differences as:

$$
\begin{aligned}
& \left(\mathrm{c}_{t}-\mathrm{c}_{t}^{*}\right)-\left(\mathrm{s}_{t}+\mathrm{p}_{t}^{*}-\mathrm{p}_{t}\right)+2 \mathrm{~b}_{t+1} \\
= & \left(\mathrm{rev}_{t}-\mathrm{rev}_{t}^{*}-\mathrm{s}_{t}\right)+\frac{1}{\beta} 2 \mathrm{~b}_{t} \\
& -\frac{1-\beta}{\beta} 2 b_{H 0} \mathrm{~s}_{t}+\left(d i_{t}-d i_{t}^{*}\right) 2 b_{H 0}
\end{aligned}
$$

(29) shows that any cross country difference in consumption, adjusted for PPP deviations, and savings reflects several sources. The first two, given by the first two terms on the right hand side, are the usual difference in the sales revenue, and the presence of net claims at the beginning of the period. The third source is the center of our analysis and reflects the impact of the exchange rate on the valuation of gross foreign assets. When the home country is a debtor in home currency bonds $\left(b_{H 0}>0\right)$, a depreciation of its currency leads to a capital gain on its assets, allowing for an increase in consumption. The final source reflects any interest rate differentials between home and foreign currency bonds. 
From (29) we can decompose the current accounts between its two main components:

$$
\mathrm{ca}_{t}=2\left(\mathrm{~b}_{t+1}-\mathrm{b}_{t}\right)=\mathrm{tb}_{t}+\mathrm{nfi}_{t}
$$

where $\mathrm{ca}_{t}$ is the current account, $\mathrm{tb}_{t}$ is the trade balance, and $\mathrm{nfi}_{t}$ is the net factor income, defined as:

$$
\begin{aligned}
\mathrm{tb}_{t} & =\left(\operatorname{rev}_{t}-\mathrm{rev}_{t}^{*}-\mathrm{s}_{t}\right)-\left(\mathrm{p}_{t}-\mathrm{p}_{t}^{*}-\mathrm{s}_{t}\right)-\left(\mathrm{c}_{t}-\mathrm{c}_{t}^{*}\right) \\
\mathrm{nfi}_{t} & =2\left[\frac{1-\beta}{\beta} \mathrm{b}_{t}+b_{H 0}\left(d i_{t}-d i_{t}^{*}\right)-\frac{1-\beta}{\beta} b_{H 0} \mathrm{~s}_{t}\right]
\end{aligned}
$$

Note that $\mathrm{b}_{t}$ does not represent the net value of foreign assets, as it ignores the valuation effects of exchange rate movements. Instead the net value of foreign assets at the end of period $t$ is:

$$
\operatorname{napf}_{t}=2\left(\mathrm{~b}_{t+1}-b_{H 0} \mathbf{s}_{t}\right)
$$

We now derive the full-blown solution of the model. We start with a version with only traded goods $(\gamma=0)$, implying that PPP holds, as this allows for an illustration of the key mechanisms while keeping the complexity of the model to a minimum. We then discuss the solution in the presence of non-traded goods.

\subsection{A model with purchasing power parity}

We first look at the case where goods prices are fully flexible and are adjusted immediately following the shocks. As shown in the Appendix, monetary shocks have no real effects in terms of worldwide average $\left(\mathrm{y}_{t}^{w}=\mathrm{c}_{t}^{w}=0\right.$, $\forall t$ ), but lead to a permanent cross-country differential in consumption:

$$
\begin{aligned}
\mathrm{s}_{\text {Flex }} & =\frac{\beta \lambda}{\beta \lambda-2 b_{H 0}(1-\beta)}\left(\overline{\mathrm{m}}-\overline{\mathrm{m}}^{*}\right) \\
\mathrm{c}_{\text {Flex }}-\mathrm{c}_{\text {Flex }}^{*} & =-\frac{2 b_{H 0}(1-\beta)}{\beta \lambda-2 b_{H 0}(1-\beta)}\left(\overline{\mathrm{m}}-\overline{\mathrm{m}}^{*}\right) \\
\mathrm{y}_{\text {Flex }}-\mathrm{y}_{\text {Flex }}^{*} & =-\lambda\left(\mathrm{c}_{\text {Flex }}-\mathrm{c}_{\text {Flex }}^{*}\right)
\end{aligned}
$$

where the "Flex" subscript denotes the solution under flexible prices. (34)(36) show that when the two countries are initially debtor in bonds denominated in their own currencies $\left(b_{H 0}<0\right)$, a monetary expansion in the home 
country leads to a depreciation of its currency, as usual. This depreciation generates a positive valuation effect of gross assets for the home country, which translates in a permanent increase in consumption. The increase in wealth stemming from the valuation effect also leads to a reduction in home output, i.e. effort. In terms of welfare, combining (27)-(28) shows that the home country benefits from its monetary expansion:

$$
\begin{aligned}
\mathrm{u}_{\text {Flex } t}-\mathrm{u}_{\text {Flex } t}^{*} & =\frac{1}{1-\beta}\left[\left(\mathrm{c}_{\text {Flex }}-\mathrm{c}_{\text {Flex }}^{*}\right)-\frac{\theta-1}{\theta}\left(\mathrm{y}_{\text {Flex }}-\mathrm{y}_{\text {Flex }}^{*}\right)\right] \\
& =-\left[1+\frac{\theta-\lambda}{\lambda \theta}\right] \frac{2 b_{H 0}}{\beta} \mathrm{s}_{\text {Flex }} \\
& =-\left[1+\frac{\theta-\lambda}{\lambda \theta}\right] \frac{2 b_{H 0} \lambda}{\beta \lambda-2 b_{H 0}(1-\beta)}\left(\overline{\mathrm{m}}-\overline{\mathrm{m}}^{*}\right)
\end{aligned}
$$

(37) shows that even when prices are fully flexible, monetary shocks lead to a non-trivial welfare effect when the initial gross asset positions are not zero. If home and foreign goods are close substitutes $(\lambda=\theta)$, the relative welfare is approximately (as $\beta$ is close to unity):

$$
\mathrm{u}_{\mathrm{Flex} t}-\mathrm{u}_{\mathrm{Flex} t}^{*} \simeq-2 b_{H 0}\left(\overline{\mathrm{m}}-\overline{\mathrm{m}}^{*}\right)
$$

We now move to the outcome under sticky prices. Following the usual approach in the literature, we consider that the monetary shocks are unexpected. The economy is initially at the symmetric steady state. Following the shocks, prices cannot be adjusted for one period (the short run). We assume that prices are set in the currency of the firm and the price paid by customers abroad moves fully with the exchange rate, i.e. there is full exchange rate pass-through. Prices are subsequently adjusted and the economy then moves to a new steady-state (the long run). We follow the convention of denoting long-run variables with an upper bar.

In worldwide terms, the monetary shocks have the usual short run real effect: $\mathrm{y}^{w}=\mathrm{c}^{w}=\overline{\mathrm{m}}^{w}, \overline{\mathbf{y}}^{w}=\overline{\mathrm{c}}^{w}=0$. In terms of cross-country differences, the exchange rate immediately reaches its new value and the consumption differential is permanent. Following the steps presented in the Appendix we write:

$$
\mathrm{s}_{\text {Sticky }}=\frac{\beta+(\lambda-1) \beta^{2}}{\beta \lambda-2 b_{H 0}(1-\beta)}\left(\overline{\mathrm{m}}-\overline{\mathrm{m}}^{*}\right)
$$

where the "Sticky" subscript denotes the solution under sticky prices. The 
relative consumption, output and trade balance are:

$$
\begin{aligned}
\mathrm{c}_{\text {Sticky }}-\mathrm{c}_{\text {Sticky }}^{*} & =(1-\beta) \frac{\beta(\lambda-1)-2 b_{H 0}}{\beta \lambda-2 b_{H 0}(1-\beta)}\left(\overline{\mathrm{m}}-\overline{\mathrm{m}}^{*}\right) \\
\mathrm{y}_{\text {Sticky }}-\mathrm{y}_{\text {Sticky }}^{*} & =\lambda \beta \frac{1+(\lambda-1) \beta}{\beta \lambda-2 b_{H 0}(1-\beta)}\left(\overline{\mathrm{m}}-\overline{\mathrm{m}}^{*}\right) \\
\mathrm{tb}_{\text {Sticky }} & =\frac{\lambda(\lambda-1) \beta^{2}+2 b_{H 0}(1-\beta)}{\beta \lambda-2 b_{H 0}(1-\beta)}\left(\overline{\mathrm{m}}-\overline{\mathrm{m}}^{*}\right)
\end{aligned}
$$

The long run effects are driven by the changes in the value of the net foreign asset position, which reflect both the current account and the valuation effect of exchange rate movements. The current account and the value of the net foreign asset position are written as:

$$
\begin{aligned}
\text { ca }_{\text {Sticky }} & =2 \mathrm{~b}_{\text {Sticky }}=(\lambda-1) \beta\left(\overline{\mathrm{m}}-\overline{\mathrm{m}}^{*}\right) \\
\text { napf }_{\text {Sticky }} & =2 \mathrm{~b}_{\text {Sticky }}-2 b_{H 0} \mathrm{~s}_{\text {Sticky }}
\end{aligned}
$$

(39)-(43) allow us to assess the impact of different levels of $b_{H 0}$ on the various variables. For simplicity, we define the ratio $D[\mathrm{x}]$ as the ratio between the value of $\mathrm{x}$ when $b_{H 0} \neq 0$ and its value when $b_{H 0}=0$. To further simplify the results, notice that $\beta$ is close to unity, so $1-\beta \simeq 0$. (39)-(43) then imply:

$$
\begin{aligned}
D\left[\mathrm{~s}_{\text {Sticky }}\right] & =D\left[\mathrm{y}_{\text {Sticky }}-\mathrm{y}_{\text {Sticky }}^{*}\right]=D\left[\mathrm{tb}_{\text {Sticky }}\right]=D\left[\mathrm{ca}_{\text {Sticky }}\right]=1 \\
D\left[\mathrm{c}_{\text {Sticky }}-\mathrm{c}_{\text {Sticky }}^{*}\right] & =D\left[\text { napf }_{\text {Sticky }}\right]=1-\frac{2 b_{H 0}}{\lambda-1}
\end{aligned}
$$

The initial gross asset position of the home country in home currency bonds has little influence on the sensitivity of the exchange rate to monetary shocks. Similarly, the short run output, trade balance, and current account are only moderately affected by $b_{H 0}$. By contrast $b_{H 0}$ has a direct influence on the value of the net asset position. When the home is a debtor in home currency bonds $\left(b_{H 0}<0\right)$, a depreciation in the home currency increases the home currency value of its foreign assets. This wealth transfer from the foreign to the home country leads to a permanent increase in home consumption and affects the long run variables. In particular, it leads to a reduction in long run output as the home country is now wealthier (recalling that $\left.\overline{\mathrm{y}}_{\text {Sticky }}-\overline{\mathrm{y}}_{\text {Sticky }}^{*}<0\right)$ :

$$
D\left[\overline{\mathrm{y}}_{\text {Sticky }}-\overline{\mathrm{y}}_{\text {Sticky }}^{*}\right]=1-\frac{2 b_{H 0}}{\lambda-1}
$$


The impact of $b_{H 0}$ on the sensitivity of consumption to monetary shocks translates directly into a substantial impact in terms of welfare. Intuitively, when $b_{H 0}=0$, an increase in consumption in the home country requires an increase in effort in order to generate the export revenue necessary to purchase extra imported consumption. The effect in terms of welfare is then fairly moderate, as the movements in consumption and welfare substantially offset each other. When $b_{H 0} \neq 0$ by contrast, the additional response in consumption comes entirely from a wealth transfer through the exchange rate impact on asset valuation. As no increase in output is required to fund the increase in consumption, the impact in terms of welfare is much larger.

Formally, we use (27)-(28) and the current accounts in the short and the long run to write:

$$
\mathrm{u}_{\text {Stickyt }}-\mathrm{u}_{\text {Sticky } t}^{*}=-\frac{1}{\beta} 2 b_{H 0} \mathrm{~s}_{\text {Sticky }}+\frac{\lambda-\theta}{\lambda \theta}\left(\mathrm{y}_{N P V \text { Sticky }}-\mathrm{y}_{N P V \text { Sticky }}^{*}\right)
$$

where the net present value of output movements is:

$$
\begin{gathered}
\mathrm{y}_{N P V \text { Sticky }}-\mathrm{y}_{N P V \text { Sticky }}^{*}=\left(\mathrm{y}_{\text {Sticky }}-\mathrm{y}_{\text {Sticky }}^{*}\right)+\frac{\beta}{1-\beta}\left(\overline{\mathrm{y}}_{\text {Sticky }}-\overline{\mathrm{y}}_{\text {Sticky }}^{*}\right) \\
=\lambda \beta \frac{1+2 b_{H 0}}{\beta \lambda-2 b_{H 0}(1-\beta)}\left(\overline{\mathrm{m}}-\overline{\mathrm{m}}^{*}\right) \\
\Rightarrow D\left[\mathrm{y}_{N \text { PVSticky }}-\mathrm{y}_{N P V \text { Sticky }}^{*}\right]=1+2 b_{H 0}
\end{gathered}
$$

(45) shows that the sensitivity of output, and consumption, to monetary shocks over the entire future is sensitive to $b_{H 0}$, even with $\beta$ close to unity. (44) shows that the relative welfare effect consist of two elements. The first reflects the effect of exchange rate movements on the value of gross foreign assets. The second is the usual term reflecting the net present value of the increase in output, adjusted for the differential in the elasticities of substitution $\lambda$ and $\theta$.

We illustrate our results with a simple numerical example. We set $\beta=$ 0.96, $\theta=6$, and consider two possible values for the elasticity of substitution between home and foreign traded goods: $\lambda=1$, and $\lambda=\theta=6$. We let the initial ratio of home-currency bonds held by the home household to GDP, $b_{H 0}$, vary from -0.4 to 0.4 . Our analysis of the currency composition of the U.S. international portfolio indicates that a value of -0.4 is reasonable for the U.S. ${ }^{8}$

\footnotetext{
${ }^{8}$ If we consider that the holdings in Caribbean currencies are de-facto holdings in U.S. dollar, the value $b_{H 0}$ of is still substantial at -0.35 .
} 
We illustrate the response to a unit monetary shock in the home country in figures 5 to 7 . The horizontal axis in each figure is $b_{H 0}$. The top row of each figure depicts the solution under flexible prices, while the bottom row presents the solution under sticky prices.

The left part of figure 5 shows the response of the exchange rate, s, with the thin and thick lines correspond to $\lambda=1$ and $\lambda=6$ respectively. The exchange rate is more responsive the higher $b_{H 0}$, especially when home and foreign goods are poor substitutes $(\lambda=1)$, although the influence of $b_{H 0}$ remains of limited magnitude. The right part of figure 5 is the response in relative consumption, $\mathrm{c}-\mathrm{c}^{*}$. Home consumption is larger when the home country is a debtor in home-currency bonds $\left(b_{H 0}<0\right)$ as the depreciation of the home currency then generates a favorable valuation effect. The sensitivity of relative consumption to $b_{H 0}$ is larger when home and foreign goods are poor substitutes.

Figure 6 presents the welfare effects of a home monetary expansion when home and foreign goods are close substitutes $(\lambda=6)$. The left part of the figure shows the home welfare, $\mathrm{u}$, while the right part presents the foreign welfare, $\mathbf{u}^{*}$. Three key points emerge from figure 6 . First, the home country benefits most from its monetary expansion when it is a debtor in home-currency bonds, with the foreign country suffering. Second, the welfare impact through the valuation effect of exchange rate movements is of substantial magnitude. Under sticky prices a 1 percent increase in the home monetary stance $(\overline{\mathrm{m}}=1)$ translates into a gain equivalent to a 0.08 percent increase in short run consumption, both for the home and the foreign countries, when $b_{H 0}=0$. If $b_{H 0}=-0.2$, the home country gain is equivalent to a 0.28 percent increase in consumption, while the foreign country suffers a loss corresponding to 0.12 percent of consumption. If $b_{H 0}=-0.4$, the home country gain increases to 0.48 percent, while the foreign loss reaches 0.32 percent. Ignoring the valuation effect of exchange rate movements therefore leads to very misleading results. Under a parametrization corresponding to the current situation of the U.S. $\left(b_{H 0}=-0.4\right)$, the welfare gain for the home country is 6 times larger than in the baseline case $\left(b_{H 0}=0\right)$, while the foreign country suffers a loss of substantial magnitude.

The final key point of figure 6 is that the welfare impact through the valuation effect of exchange rate does not hinge on price rigidities. When prices are flexible, the home monetary expansion has no effect when $b_{H 0}=0$. When $b_{H 0}=-0.2$, the depreciation of the home currency leads to a gain for the home country that is equivalent to a 0.21 percent increase in consumption, 
with an offsetting loss for the foreign country. If $b_{H 0}=-0.4$, the gain for the home country increases to a 0.41 percent. The magnitude of these effects is similar to the one under sticky prices.

Figure 7 is similar to figure 6 , and corresponds to the case where home and foreign goods are poor substitutes $(\lambda=1)$. It shows that the welfare impact of exchange rate movement through the valuation of foreign assets is still substantial. Furthermore the results are more sensitive to $b_{H 0}$ when the substitutability between home and foreign goods is low. ${ }^{9}$ Intuitively, (44) shows that when $\lambda<\theta$ the home country is adversely affected, relative to the foreign country, by a home monetary expansion, as discussed in Tille (2001). While the depreciation of the home currency boosts home output, as shown by (45), this comes at a prohibitive cost though a worsening in the home country terms-of-trade. (45) shows that the increase in output is smaller the more negative $b_{H 0}$ is. Therefore a negative $b_{H 0}$ benefits the home country in two ways. First, it leads a depreciation of the exchange rate that generates a valuation gain in the home country foreign assets, captured by the first element in (44). Second, it reduces the magnitude of the detrimental increase in home output.

\subsection{The influence of nontraded goods}

Allowing for non-traded goods $(\gamma>0)$ makes the model more complex. In particular, it leads to a breakdown of PPP, and richer consumption dynamics than in the baseline model with only traded goods. Yet, the additional complexity of the model does not affect the main message of the paper, as the dominant mechanism through which monetary shocks affect welfare remains the valuation impact of exchange rate movements on gross asset positions.

We leave the exposition of the model with non-traded goods to the Appendix, and focus on a numerical illustration of the results, focusing on the welfare for brevity. Figure 8 presents the welfare impact of a monetary expansion in the home country for various sizes of the non-traded sector. We focus on the case where home and foreign traded goods and non-traded goods are close substitutes $(\lambda=\theta=6)$. The thin dotted line in each panel shows the welfare effect when all goods are traded $(\gamma=0)$, corresponding to figure 6 . The thick solid line corresponds to $\gamma=0.75$, an empirically reasonable value. The thin solid line illustrates a case where only a few goods are traded

\footnotetext{
${ }^{9}$ The slopes of the lines in figure 7 are steeper than in figure 6 .
} 
$(\gamma=0.95)$, and both countries are nearly closed economies.

The main point of figure 8 is that the welfare effects of monetary shocks are little affected by the presence of non-traded goods. When prices are fully flexible, the extreme cases of $\gamma=0$ and $\gamma=0.95$ are nearly indistinguishable, as shown in the top row of figure 8 . When prices are sticky, the presence of non-traded goods generates a welfare differential in favor of the home country, as discussed in Hau (2000). Yet, the dominant feature remains the sensitivity of the welfare effects to the gross asset positions $b_{H 0}$. Looking at the home welfare (bottom left panel), the impact when $b_{H 0}=-0.4$ is 6 times larger than when $b_{H 0}=0$ in the absence of non-traded goods. When most goods are traded $(\gamma=0.95)$, the home welfare effect is more than three times as large when $b_{H 0}=-0.4$ as when $b_{H 0}=0$.

\section{Conclusion}

This paper presents a novel channel through which exchange rate movements are transmitted across countries. When countries hold large offsetting asset and liability positions in different currencies, exchange rate movements lead to substantial wealth transfers in addition of their usual effect on international trade. We focus on the case of the U.S. and show that the fluctuations of the value of the dollar in recent years has substantially impacted the U.S. international investment position. While nearly all U.S. liabilities to foreign investors are in dollar, two-thirds of U.S. assets are denominated in foreign currencies. A depreciation of the dollar, such as the one observed in 2002 and 2003, then boosts the value of U.S. assets, with the effect amounting to nearly 4 percent of GDP in 2003.

In the first part of the paper, we undertake a detailed breakdown of the currency composition of the U.S. portfolio, and show that European currencies account for half the foreign currency assets held by U.S. investors, while the weight of Asian currencies is mcuh smaller. The valuation effect of exchange rate movements on the U.S. portfolio are then larger when the dollar move against European currencies. We also document that the large weight of European currencies substantially exceeds the importance of these countries as trading partners for the U.S.

Our next step is to analyze the relevance of the valuation channel of exchange rate movements using a standard open economy general equilibrium model. The results are striking. Calibrating the gross asset position to reflect 
the current U.S. situation, we find that the main welfare effect of exchange rate fluctuations comes through changes in the valuations of foreign assets. The welfare effect of monetary shocks are between 3 to 6 times larger when we include the valuation channel, depending on the specification of the model. This indicates that the usual effects through movements in the trade balance are a secondary mechanism. Furthermore, the welfare fluctuations through the valuation channel are not only very large, but do not hinge on the presence of price rigidities and operate even when good prices are fully flexible.

While our setup is limited, the large wealth transfers stemming from the impact of exchange rate movements on the value of foreign assets and liabilities point to fruitful avenues for future research. First, we take the currency composition of the international portfolio as given. Developing an optimal portfolio model to explain why investors are short in their own currency and long in foreign ones is an important extension. Second, the large effects that the model indicate may provide a new angle in the analysis of the relative costs and benefits of flexible and fixed exchange rate regimes. Finally, they may also limit the scope for risk sharing, as taking large positions in assets denominated in foreign currencies can itself be a source of wealth volatility. 


\section{References}

[1] Abaroa, Patricia (2004), The International Investment Position of the United States at Yearend 2003, Survey of Current Business 84 (7), Bureau of Economic Analysis, pp. 30-39.

[2] Bureau of Economic Analysis (2003), U.S. Direct Investment Position Abroad on a Historical-Cost Basis 2003.

[3] Federal Reserve Bank of New York, Board of Governors of the Federal Reserve, U.S. Department of the Treasury (2002), Foreign Holdings of U.S. Securities as of June 30, 2002.

[4] Federal Reserve Bank of New York, Board of Governors of the Federal Reserve, U.S. Department of the Treasury (2001), U.S. Holdings of Foreign Securities as of December 31, 2001.

[5] Gourinchas, Pierre-Olivier, and Helene Rey (2004), International Financial Adjustment, mimeo, Princeton University.

[6] Hau, Harald (2000), Exchange Rate Determination: The Role of Factor Price Rigidities and Nontradeables, Journal of International Economics 50, pp. 421-447.

[7] Lane, Philip, and Gian Maria Milesi-Ferretti (2004), Financial Globalization and Exchange Rates, mimeo.

[8] Lane, Philip, and Gian Maria Milesi-Ferretti (2003), International Financial Integration, International Monetary Fund Staff Papers, 50.

[9] Obstfeld, Maurice, and Kenneth Rogoff (1995), Exchange Rate Dynamics Redux, Journal of Political Economy 103, pp. 624-660.

[10] Tille, Cedric (2003), The Impact of Exchange Rate Movements on U.S. Foreign Debt, Current Issues In Economics and Finance 9 (1), Federal Reserve Bank of New York.

[11] Tille, Cedric, (2001), The Role of Consumption Substitutability in the International Transmission of Shocks, Journal of International Economics 53, pp. 421-444. 


\section{Appendix}

\subsection{The currency composition of U.S. assets and lia- bilities}

\subsubsection{U.S. assets}

U.S. official assets at then end of 2003 are allocated based on the BEA figures in Abaroa (2004). U.S. official reserves assets $(\$ 183,577 \mathrm{mls})$ consist of $\$ 108,866 \mathrm{mls}$ in gold, $\$ 35,173 \mathrm{mls}$ of SDR and the position at the IMF, and $\$ 39,538 \mathrm{mls}$ in FX reserves. Based on the Treasury data on U.S. International Reserve Position as of December 26 2003, $\$ 21,916 \mathrm{mls}$ of the later are in Euro with the balance in Yen. U.S. official assets other than reserves $(\$ 84,772$ mls) include $\$ 3,066 \mathrm{mls}$ in foreign currencies.

The currency composition of U.S. equity is estimated based on the Survey of U.S. holdings of foreign securities (Federal Reserve Bank of New York et al. 2001, table 14). The survey breaks down the total equity holdings by U.S. investors $(\$ 1,612,673 \mathrm{mls})$ across a large number of countries. We assume that equity holdings in a country are denominated in the currency of that country, with the currencies taken from the CIA world factbook. We group several different countries into some currency blocks for the euro, the U.K. pound, the U.S. dollar and the Swiss franc. ${ }^{10}$ We use the shares of the various currencies in 2001 to allocate the U.S. equity assets at the end of 2003 (\$ $1,972,244 \mathrm{mls}$ ) across the various countries.

We also use the Survey of U.S. holdings of foreign securities (Federal Reserve Bank of New York et al. 2001, table 16) to allocate the U.S. holdings of long term debt across currencies, totalling $\$ 502,062 \mathrm{mls}$ at the end of 2001 . The survey gives the value of debt denominated in U.S. dollar, U.K. pound, euro, yen and own currency for each country. We start by adjusting the data in own currency for double counting, as for instance euro denominated debt for France also appears under the 'own currency' category. We remove from the 'own currency' data debt for countries that use the euro, the U.S. dollar, the U.K. pound. ${ }^{11}$ Switzerland and Liechtenstein are slao grouped under the

\footnotetext{
${ }^{10}$ The specific aggregation is: euro (Austria, Belgium, Germany, Finland, France, Greece, Ireland, Italy, Luxembourg, Monaco, Netherlands, Portugal, Spain), pound (Guernsey, Isle of Man, Jersey, U.K.), U.S. dollar (British Virgin Island, Ecuador, Salvador, Marshall Islands, Panama, Turk and Cacaio), Swiss franc (Liechtenstein, Switzerland).

${ }^{11}$ Specifically: euro (Austria, Belgium, Germany, Finland, France, Greece, Ireland, Italy,
} 
Swiss franc. The adjusted 'own currency' category then totals $\$ 35,339 \mathrm{mls}$, with is sligghtly smaller that substracting the amounts of U.S. dollar, pond, yen and euro from the total debt assets, which leads to $\$ 36,815 \mathrm{mls}$. We reconcile the two number by taking the adjusted 'own currency' number as the true own currency values for the top 18 trading partners, and allocate the $\$ 1,476 \mathrm{mls}$ gap across the various regions of the rest of the world. We use the estimated shares of the various currencies to allocate the debt assets at the end of 2003, amounting to $\$ 502,130 \mathrm{mls}$.

Our allocation of FDI assets across currency relies on the geographical data published by the BEA (2003). While the data are on a historical cost basis (totalling $\$ 1,788,911 \mathrm{mls}$ ), unlike the figures for the U.S. assets and liabilities where FDI is evaluated at market value (totalling $\$ 2,730,289 \mathrm{mls}$ ), we use them to compute the share of the various currencies and apply them to the market value data. We assume that FDI holdings in a country are denominated in the currency of that country. We aggregate countries for the euro and the U.S. dollar. ${ }^{12}$ The country breakdown is less detailed than the one for equity holdings (Federal Reserve Bank of New York et al. 2001, table 14). We estimate the FDI assets in Liechstenstein ( $\$ 67 \mathrm{mls}$ ) by relying on the equity assets in the Liechstenstein and Switzerland, as well as the value of FDI assets in Switzerland. The amount is allocated to the Swiss franc, and out of the 'other Europe' category. We compute an estimate of FDI holdings in Salvador ( $\$ 23 \mathrm{mls}$ ) by using the total FDI and equity assets in Latin America, minus Mexico, Panama, Brazil and Ecuador, and the equity assets in Salvador. The amount is allocated to the U.S. dollar and taken out of the 'other central America' category. The category 'U.K. Islands, Caribbean' is allocated across the U.S. dollar, the U.K. pound and local currencies by relying on equity assets in the corresponding countries. ${ }^{13}$

The BEA reports that at the end of $2003 \$ 104,400$ mls worth of banking assets were denominated in foreign currencies, out of a total of of $\$ 1,776,284$ mls (Abaroa 2004, table D and table 1). While no figures are available for

Luxembourg, Monaco, Netherlands, Portugal, Spain). pound (Guernsey, Isle of Man, Jersey, U.K), U.S. dollar (British Virgin Island, Ecuador, Salvador, Marshall Islands, Panama, Turk and Cacaio).

${ }^{12}$ Specifically: euro (Austria, Belgium, Germany, Finland, France, Greece, Ireland, Italy, Luxembourg, Netherlands, Portugal, Spain), U.S. dollar (Ecuador, Panama).

${ }^{13}$ Specifically, the allocation is: U.S. dollar (British Virgin Islands, Turk and Cacaio), pound (Guernsey, Isle of Man, Jersey), own currency (Aruba, Cayman, Grenada, Jamaica, Trinidad and Tobago). 
the currency composition of 'other' assets, the valuation effect of exchange rate movements reported by the BEA is similar to that of banking assets, suggesting a similar amount of foreign currency denominated debt for the 'other' category, that we estimate at $\$ 124,172 \mathrm{mls}$ out of a total of $\$ 614,672$ mls.

\subsubsection{U.S. liabilities}

The BEA data indicate that the only categoreis of U.S. liabilities including some securities denominated in foreign currencies are debt securities, banks and other, as the valuation impact of exchange rate movements is zero for all other categories (Abaroa 2004, table 1).

The currency composition of debt liabilities, excluding Treasury securities, is estimated based on the Survey of foreign holdings of U.S. securities (Federal Reserve Bank of New York et al. 2002, table 22). As of June 30, 2002, foreign investors held $\$ 2,530,517$ millions of U.S. long term debt securities, of which $\$ 908,058 \mathrm{mls}$ consisted of Treasury debt (table 17) denominated in dollar. The currency composition of the remaining debt is given in table 22. We use the share of the various currencies in the non-Tresury debt liabilities to allocate the amount at the end of 2003 (\$1,852,971 mls).

The BEA reports that at the end of $2003 \$ 61,500 \mathrm{mls}$ worth of banking liabilities were denominated in foreign currencies, out of a total of of $\$$ 1,887,215 mls (Abaroa 2004, table I and table 1). While no figures are available for the currency composition of 'other' liabilities, the valuation effect of exchange rate movements reported by the BEA is similar to that of banking liabilities, suggesting a similar amount of foreign currency denominated debt for the 'other' category, that we estimate at $\$ 62,448 \mathrm{mls}$ out of a total of $\$$ 466,543 mls.

\subsubsection{U.S. exports}

The composition of U.S. trade across the various countries, grouped by the currency they used, is computed based on the data for international trade in goods in 2003 from the BEA. We group the detailed breakdown of countries for euro, U.K. pound, U.S. dollar, Norwegian krone, Danish krone, Australian dollar, New Zealand dollar, Swiss franc. ${ }^{14}$

\footnotetext{
${ }^{14}$ Specifically: euro (Andorra, Austria, Belgium, Germany, Finland, France, French Guyana, French South Islands, Greece, Guadeloupe, Ireland, Italy, Luxembourg, Mar-
} 


\subsection{Linear approximations}

The approximations for most relations is standard. The consumer price indexes (2) and (3) are:

$$
\begin{aligned}
\mathrm{p} & =\frac{1-\gamma}{2-\gamma}\left[\mathrm{p}_{H T}+\mathrm{s}+\mathrm{p}_{F T}^{*}\right]+\frac{\gamma}{2-\gamma} \mathbf{p}_{N} \\
\mathbf{p}^{*} & =\frac{1-\gamma}{2-\gamma}\left[\mathbf{p}_{H T}-\mathbf{s}+\mathbf{p}_{F T}^{*}\right]+\frac{\gamma}{2-\gamma} \mathbf{p}_{N}^{*}
\end{aligned}
$$

The outputs of the various firms (13)-(16) are:

$$
\begin{aligned}
\mathrm{y}_{T} & =\frac{1}{2}\left(\mathrm{c}+\mathrm{c}^{*}\right)-\lambda\left[\mathrm{p}_{H T}-\frac{1}{2} \mathrm{p}-\frac{1}{2}\left(\mathrm{~s}+\mathrm{p}^{*}\right)\right] \\
\mathrm{y}_{N} & =\mathrm{c}-\lambda\left(\mathrm{p}_{N}-\mathrm{p}\right) \\
\mathrm{y}_{T}^{*} & =\frac{1}{2}\left(\mathrm{c}+\mathrm{c}^{*}\right)-\lambda\left[\mathrm{p}_{F T}^{*}-\frac{1}{2}(\mathrm{p}-\mathrm{s})-\frac{1}{2} \mathrm{p}^{*}\right] \\
\mathrm{y}_{N}^{*} & =\mathrm{c}^{*}-\lambda\left(\mathrm{p}_{N}^{*}-\mathrm{p}^{*}\right)
\end{aligned}
$$

We define the country-wide average of outputs as:

$$
\mathrm{y}=\frac{\gamma}{2-\gamma} \mathrm{y}_{N}+\frac{2-2 \gamma}{2-\gamma} \mathrm{y}_{T} \quad \mathrm{y}^{*}=\frac{\gamma}{2-\gamma} \mathrm{y}_{N}^{*}+\frac{2-2 \gamma}{2-\gamma} \mathrm{y}_{T}^{*}
$$

The sales revenues (19)-(20) are:

$$
\begin{aligned}
\text { rev } & =\frac{\gamma}{2-\gamma} p_{N}+\frac{2-2 \gamma}{2-\gamma} p_{H T}+\mathrm{y} \\
\operatorname{rev}^{*} & =\frac{\gamma}{2-\gamma} \mathrm{p}_{N}^{*}+\frac{2-2 \gamma}{2-\gamma} \mathrm{p}_{F T}^{*}+\mathrm{y}^{*}
\end{aligned}
$$

where we used the steady-state expressions: $R E V_{0}=P_{0} C_{0}=S_{0} R E V_{0}^{*}$. The money demands (5) and (10) are:

$$
\mathrm{m}_{t}-\mathrm{p}_{t}=\mathrm{c}_{t}-\frac{\beta}{1-\beta} \beta d i_{t+1} \quad \mathrm{~m}_{t}^{*}-\mathrm{p}_{t}^{*}=\mathrm{c}_{t}^{*}-\frac{\beta}{1-\beta} \beta d i_{t+1}^{*}
$$

tinique, Mayotte, Monaco, Netherlands, Portugal, Reunion, San Marino, Spain, St Pierre et Miquelon, Vatican), pound (British Indian Ocean territory, U.K.), U.S. dollar (British Virgin Island, East Timor, Ecuador, Salvador, Marshall Islands, Palau, Panama, Turk and Cacaio), Norwegian krone (Norway, Jan Mayen Island), Danish krone (Denmark, Faroe Islands, Greenland), Australian dollar (Australia, Christmas Island, Cocos Islands, Kiribati, Nauru, Norfolk Islands, Tuvalu), New Zealand dollar (Cook Islands, New Zealand, Niue, Pitcairn Islands), Swiss franc (Liechtenstein, Switzerland). 
The labor supplies (6) and (11) are:

$$
\mathrm{w}_{t}=\mathrm{p}_{t}+\mathrm{c}_{t} \quad \mathrm{w}_{t}^{*}=\mathrm{p}_{t}^{*}+\mathrm{c}_{t}^{*}
$$

The Euler conditions (7) and (12) are:

$$
\begin{aligned}
& \mathrm{c}_{t+1}=\mathrm{c}_{t}+\beta d i_{t+1}-\left(\mathrm{p}_{t+1}-\mathrm{p}_{t}\right) \\
& \mathrm{c}_{t+1}^{*}=\mathrm{c}_{t}^{*}+\beta d i_{t+1}^{*}-\left(\mathrm{p}_{t+1}^{*}-\mathrm{p}_{t}^{*}\right)
\end{aligned}
$$

The interest parity (8) is:

$$
\beta d i_{t+1}=\beta d i_{t+1}^{*}+\left(\mathrm{s}_{t+1}-\mathrm{s}_{t}\right)
$$

The optimal prices (17) are:

$$
\mathrm{p}_{H T}=\mathrm{p}_{N}=\mathrm{w} \quad \mathrm{p}_{F T}^{*}=\mathrm{p}_{N}^{*}=\mathrm{w}^{*}
$$

The current accounts (21)-(22) have a more general forms that in existing contributions. We start expanding the home current account (21) by writing:

$$
\begin{aligned}
& P_{0} C_{0}\left(\mathrm{p}_{t}+\mathrm{c}_{t}\right)+\left(B_{H t+1}-B_{H 0}\right)+S_{0}\left(B_{F t+1}-B_{F 0}\right)+S_{0} B_{F 0} \mathrm{~s}_{t} \\
= & R E V_{0} \mathrm{rev}_{t}+d i_{t} B_{H 0}+\frac{1}{\beta}\left(B_{H t}-B_{H 0}\right) \\
& +d i_{t}^{*} S_{0} B_{F 0}+\frac{1}{\beta} S_{0}\left(B_{F t}-B_{F 0}\right)+\frac{1}{\beta} S_{0} B_{F 0} \mathrm{~s}_{t}
\end{aligned}
$$

Using (24), along with the fact that $P_{0} C_{0}=R E V_{0}$, we write:

$$
\mathrm{p}_{t}+\mathrm{c}_{t}+\mathrm{b}_{t+1}=\operatorname{rev}_{t}+\frac{1}{\beta} \mathrm{b}_{t}-\frac{1-\beta}{\beta} b_{H 0} \mathrm{~s}_{t}+\left(d i_{t}-d i_{t}^{*}\right) b_{H 0}
$$

where:

$$
\mathrm{b}_{t}=\frac{B_{H t}+S_{0} B_{F t}}{P_{0} C_{0}}
$$

Turning to the foreign current account (22) we write:

$$
\begin{aligned}
& P_{0}^{*} C_{0}\left(\mathrm{p}_{t}^{*}+\mathrm{c}_{t}^{*}\right)-\frac{1}{S_{0}}\left(B_{H t+1}-B_{H 0}\right)+\frac{1}{S_{0}} B_{H 0} \mathrm{~s}_{t}-\left(B_{F t+1}-B_{F 0}\right) \\
= & R E V_{0}^{*} \operatorname{rev}_{t}^{*}-d i_{t} \frac{1}{S_{0}} B_{H 0}-\frac{1}{S_{0}} \frac{1}{\beta}\left(B_{H t}-B_{H 0}\right)+\frac{1}{S_{0}} \frac{1}{\beta} B_{H 0} \mathrm{~s}_{t} \\
& -d i_{t}^{*} B_{F 0}-\frac{1}{\beta}\left(B_{F t}-B_{F 0}\right)
\end{aligned}
$$


Using (24), along with the fact that $P_{0}^{*} C_{0}=R E V_{0}^{*}$, we write:

$$
\mathrm{p}_{t}^{*}+\mathrm{c}_{t}^{*}-\mathrm{b}_{t+1}=\mathrm{rev}_{t}^{*}-\frac{1}{\beta} \mathrm{b}_{t}+\frac{1-\beta}{\beta} b_{H 0} \mathrm{~s}_{t}-\left(d i_{t}-d i_{t}^{*}\right) b_{H 0}
$$

We define a couple of cross-country variables related to the current account and asset holdings. The first is the trade balance:

$$
\mathrm{tb}_{t}=\left(\operatorname{rev}_{t}-\operatorname{rev}_{t}^{*}\right)-\left(\mathrm{p}_{t}-\mathrm{p}_{t}^{*}\right)-\left(\mathrm{c}_{t}-\mathrm{c}_{t}^{*}\right)
$$

In terms of cross-country differences, the net factor income is written as:

$$
N F I_{t}=\left[i_{t} B_{H t}+S_{t} i_{t}^{*} B_{F t}\right]-\left[i_{t} B_{H t}^{*}+S_{t} i_{t}^{*} B_{F t}^{*}\right]
$$

which is approximated as:

$$
\mathrm{nfi}_{t}=\frac{d N F I_{t}}{P_{0} C_{0}}=2\left(\frac{1-\beta}{\beta} \mathrm{b}_{t}+b_{H 0}\left(d i_{t}-d i_{t}^{*}\right)-\frac{1-\beta}{\beta} b_{H 0} \mathrm{~s}_{t}\right)
$$

The net asset positions at the beginning and end of period $t$ are written as:

$$
\begin{aligned}
N A P I_{t} & =\left[B_{H t}+S_{t} B_{F t}\right]-\left[B_{H t}^{*}+S_{t} B_{F t}^{*}\right] \\
N A P F_{t} & =\left[B_{H t+1}+S_{t} B_{F t+1}\right]-\left[B_{H t+1}^{*}+S_{t} B_{F t+1}^{*}\right]
\end{aligned}
$$

which are written in terms of approximations as:

$$
\begin{aligned}
\text { napi }_{t} & =\frac{d N A P I_{t}}{P_{0} C_{0}}=2\left(\mathrm{~b}_{t}-b_{H 0} \mathrm{~s}_{t}\right) \\
\operatorname{napf}_{t} & =\frac{d N A P F_{t}}{P_{0} C_{0}}=2\left(\mathrm{~b}_{t+1}-b_{H 0} \mathrm{~s}_{t}\right)
\end{aligned}
$$

The current account is the sum of the trade balance and the net factor income:

$$
\mathrm{ca}_{t}=\mathrm{tb}_{t}+\mathrm{nfi}_{t}
$$

Taking the difference between (61) and (62) we write:

$$
\mathrm{ca}_{t}=\operatorname{napf}_{t}-\text { napi }_{t}=2\left(\mathrm{~b}_{t+1}-\mathrm{b}_{t}\right)
$$

Comparing the net asset position for two subsequent periods we write:

$$
\operatorname{napi}_{t+1}-\text { napi }_{t}=\mathrm{ca}_{t}-2 b_{H 0}\left(\mathrm{~s}_{t+1}-\mathrm{s}_{t}\right)
$$




\subsection{Solution of the model}

\subsubsection{The flexible price case}

We take worldwide weighted average of the consumer price indexes (46)(47), the outputs (52), the money demands (55), the Eulers (57)-(58) and the labor supplies (56), to show that there are no worldwide real effects:

$$
\mathrm{y}_{t}^{w}=\mathrm{c}_{t}^{w}=0 \quad \mathrm{p}_{t}^{w}=\overline{\mathrm{m}}^{w} \quad \forall t
$$

In terms of cross-country differences the consumer price indexes (46)-(47) imply:

$$
\mathrm{p}_{t}-\mathrm{p}_{t}^{*}-\mathrm{s}_{t}=\frac{\gamma}{2-\gamma}\left(\mathrm{w}_{t}-\mathrm{w}_{t}^{*}-\mathrm{s}_{t}\right)
$$

The outputs (52) and revenues (53)-(54) are written as:

$$
\begin{aligned}
\mathrm{y}_{t}-\mathrm{y}_{t}^{*} & =\frac{\gamma}{2-\gamma}\left(\mathrm{c}_{t}-\mathrm{c}_{t}^{*}\right)-\lambda \frac{2}{2-\gamma} \frac{2-2 \gamma}{2-\gamma}\left(\mathrm{w}_{t}-\mathrm{w}_{t}^{*}-\mathrm{s}_{t}\right) \\
\mathrm{rev}_{t}-\mathrm{rev}_{t}^{*} & =\left(\mathrm{w}_{t}-\mathrm{w}_{t}^{*}\right)+\left(\mathrm{y}_{t}-\mathrm{y}_{t}^{*}\right)
\end{aligned}
$$

The current accounts relations (61)-(62) are written as:

$$
\begin{aligned}
\frac{2-2 \gamma}{2-\gamma}\left(\mathrm{c}_{t}-\mathrm{c}_{t}^{*}\right)+2 \mathrm{~b}_{t+1}= & \frac{2-2 \gamma}{2-\gamma}\left[1-\lambda \frac{2}{2-\gamma}\right]\left(\mathrm{w}_{t}-\mathrm{w}_{t}^{*}-\mathrm{s}_{t}\right) \\
& +\frac{1}{\beta} 2 \mathrm{~b}_{t}-\frac{1-\beta}{\beta} 2 b_{H 0} \mathrm{~s}_{t}+\left(d i_{t}-d i_{t}^{*}\right) 2 b_{H 0}
\end{aligned}
$$

The labor supplies (56) provide a relation between relative wages and consumption:

$$
\left(\mathrm{c}_{t}-\mathrm{c}_{t}^{*}\right)=\frac{2-2 \gamma}{2-\gamma}\left(\mathrm{w}_{t}-\mathrm{w}_{t}^{*}-\mathrm{s}_{t}\right)
$$

The Euler conditions (57)-(58), along with the interest rate parity (59), imply:

$$
\left(c_{t+1}-c_{t+1}^{*}\right)=\left(c_{t}-c_{t}^{*}\right)-\left(p_{t+1}-p_{t+1}^{*}-s_{t+1}\right)+\left(p_{t}-p_{t}^{*}-s_{t}\right)
$$

Combining with our results so far, the consumption differential, $c_{t}-c_{t}^{*}$, the relative wage, $\mathrm{w}_{t}-\mathrm{w}_{t}^{*}-\mathrm{s}_{t}$, and the real exchange rate, $\mathrm{s}_{t}+\mathrm{p}_{t}^{*}-\mathrm{p}_{t}$, are constant. The money demand (55) is:

$$
\left(\overline{\mathrm{m}}-\overline{\mathrm{m}}^{*}\right)-\left(\mathrm{p}_{t}-\mathrm{p}_{t}^{*}-\mathrm{s}_{t}\right)-\frac{1}{1-\beta} \mathrm{s}_{t}=\left(\mathrm{c}_{t}-\mathrm{c}_{t}^{*}\right)-\frac{\beta}{1-\beta} \mathrm{s}_{t+1}
$$


Using the constant consumption differential and real exchange rate, the money demand can be iterated forward to show that the nominal exchange rate is constant, $\mathrm{s}_{t+1}=\mathrm{s}_{t}$. (59) then implies that there are no interest differentials. Combining these results with the current account leads to the following relation between consumption and the nominal exchange rate:

$$
\frac{2 \lambda-\gamma}{2-\gamma}\left(c_{t}-c_{t}^{*}\right)+\frac{1-\beta}{\beta} 2 b_{H 0} s_{t}=0
$$

The money demand (55) provides a second relation between consumption and the nominal exchange rate. Combining them we obtain:

$$
\begin{aligned}
\mathrm{c}_{t}-\mathrm{c}_{t}^{*} & =-\frac{2-2 \gamma}{2-\gamma} \frac{2 b_{H 0}(1-\beta)}{-\beta \gamma \frac{2-\gamma+(\lambda-1) \gamma}{(2-\gamma)^{2}}+\beta \lambda-2 b_{H 0}(1-\beta)}\left(\overline{\mathrm{m}}-\overline{\mathrm{m}}^{*}\right) \\
\mathrm{s}_{t} & =\frac{(2-2 \gamma)(2 \lambda-\gamma)}{(2-\gamma)^{2}} \frac{\beta}{-\beta \gamma \frac{2-\gamma+(\lambda-1) \gamma}{(2-\gamma)^{2}}+\beta \lambda-2 b_{H 0}(1-\beta)}\left(\overline{\mathrm{m}}-\overline{\mathrm{m}}^{*}\right)
\end{aligned}
$$

From the current accounts relations (61)-(62), there are no changes in the stock of net claims: $\mathrm{b}_{t+s}=0, \forall s$. (66) and (67) then imply that the current account is zero and the value of the net foreign asset position reflects the movement in the exchange rate:

$$
\mathrm{ca}_{t+s}=0 \quad, \quad \operatorname{napf}_{t+s}=-2 b_{H 0} \mathrm{~s}_{t} \quad \forall s
$$

The welfare difference is computed as:

$$
\begin{aligned}
\mathrm{u}_{t}-\mathrm{u}_{t}^{*} & =\frac{1}{1-\beta}\left[\left(\mathrm{c}_{t}-\mathrm{c}_{t}^{*}\right)-\frac{\theta-1}{\theta}\left(\mathrm{y}_{t}-\mathrm{y}_{t}^{*}\right)\right] \\
& =-\left[1+\frac{\theta-1}{\theta} \frac{2 \lambda-\gamma}{2-\gamma}\right] \frac{2-2 \gamma}{2-\gamma} \frac{2 b_{H 0}}{-\beta \gamma \frac{2-\gamma+(\lambda-1) \gamma}{(2-\gamma)^{2}}+\beta \lambda-2 b_{H 0}(1-\beta)}\left(\overline{\mathrm{m}}-\overline{\mathrm{m}}^{*}\right)
\end{aligned}
$$

\subsubsection{The sticky price case}

In the short run prices cannot move: $\mathrm{p}_{H T}=\mathrm{p}_{F T}^{*}=0$. We start by computing the solution in terms of worldwide averages. From the consumer price indexes (46)-(47), the outputs (52), the money demands (55), the Eulers (57)-(58) and the labor supplies (56), we show that the worldwide real effect is limited to the short run:

$$
\begin{aligned}
& \mathrm{y}^{w}=\mathrm{c}^{w}=\overline{\mathrm{m}}^{w} \\
& \mathrm{p}^{w}=
\end{aligned} \quad \overline{\mathrm{y}}^{w}=\overline{\mathrm{c}}^{w}=0
$$


Turning to cross-country differences, the consumer price indexes (46)(47) and the optimal prices (60) imply that the real exchange rate reflects the nominal exchange rate in the short run and the relative wages in the long run:

$$
\mathrm{p}-\mathrm{p}^{*}-\mathrm{s}=-\frac{\gamma}{2-\gamma} \mathrm{s} \quad \overline{\mathrm{p}}-\overline{\mathrm{p}}^{*}-\overline{\mathrm{s}}=\frac{\gamma}{2-\gamma}\left(\overline{\mathrm{w}}-\overline{\mathrm{w}}^{*}-\overline{\mathrm{s}}\right)
$$

Combining the the Eulers (57)-(58) and the interest rate parity (59) shows that the dynamics of consumption reflect the dynamics of the real exchange rate:

$$
\left(\bar{c}-\bar{c}^{*}\right)=\left(c-c^{*}\right)-\left(\bar{p}-\bar{p}^{*}-\bar{s}\right)+\left(p-p^{*}-s\right)
$$

Combining this results with the money demands (55) in the short and the long run, we show that the nominal exchange rate immediately reaches its long-run value:

$$
\mathrm{s}=\overline{\mathrm{s}}
$$

The interest rate parity (59) then implies that the cross-country interest rate differential is zero. The short run money demand provides a relation between the exchange rate and consumption:

$$
\left(\overline{\mathrm{m}}-\overline{\mathrm{m}}^{*}\right)-\frac{2-2 \gamma}{2-\gamma} \mathrm{s}=\left(\mathrm{c}-\mathrm{c}^{*}\right)
$$

In the long run, the outputs (52) and the current accounts (61)-(62) are written as:

$$
\begin{aligned}
& \overline{\mathrm{y}}-\overline{\mathrm{y}}^{*}=\frac{\gamma}{2-\gamma}\left(\overline{\mathrm{c}}-\overline{\mathrm{c}}^{*}\right)-\lambda \frac{2-2 \gamma}{2-\gamma} \frac{2}{2-\gamma}\left(\overline{\mathrm{w}}-\overline{\mathrm{w}}^{*}-\mathrm{s}\right) \\
& \overline{\mathrm{c}}-\overline{\mathrm{c}}^{*}=\left(\overline{\mathrm{w}}-\overline{\mathrm{w}}^{*}-\mathrm{s}\right)-\left(\overline{\mathrm{p}}-\overline{\mathrm{p}}^{*}-\mathrm{s}\right)+\left(\overline{\mathrm{y}}-\overline{\mathrm{y}}^{*}\right)+\frac{1-\beta}{\beta} 2 \mathrm{~b}-\frac{1-\beta}{\beta} 2 b_{H 0} \mathrm{~s}
\end{aligned}
$$

where we used the revenues (53)-(54) and the fact that $\mathrm{b}$ is constant. The long run labor supplies (56) imply:

$$
\left(\bar{w}-\bar{w}^{*}-s\right)=\left(\bar{p}-\bar{p}^{*}-s\right)+\left(\bar{c}-\bar{c}^{*}\right)
$$

These relations allow us to derive for the long run solution, conditional on 
the value of net foreign asset holdings:

$$
\begin{aligned}
\overline{\mathrm{c}}-\overline{\mathrm{c}}^{*} & =\frac{2-\gamma}{2 \lambda-\gamma} \frac{1-\beta}{\beta} 2\left(\mathrm{~b}-b_{H 0} \mathrm{~s}\right) \\
\overline{\mathrm{y}}-\overline{\mathrm{y}}^{*} & =-\frac{1-\beta}{\beta} 2\left(\mathrm{~b}-b_{H 0} \mathrm{~s}\right) \\
\overline{\mathrm{w}}-\overline{\mathrm{w}}^{*}-\mathrm{s} & =\frac{2-\gamma}{2 \lambda-\gamma} \frac{2-\gamma}{2-2 \gamma} \frac{1-\beta}{\beta} 2\left(\mathrm{~b}-b_{H 0} \mathrm{~s}\right)
\end{aligned}
$$

In the short run, the outputs (52) are:

$$
\mathrm{y}-\mathrm{y}^{*}=\frac{\gamma}{2-\gamma}\left(\mathrm{c}-\mathrm{c}^{*}\right)+\left[1-\frac{\gamma^{2}}{(2-\gamma)^{2}}\right] \lambda \mathrm{s}
$$

Using the revenues (53)-(54), and the fact that $\mathrm{b}_{0}=0$ initially, we write the current accounts (61)-(62) as:

$$
\mathrm{c}-\mathrm{c}^{*}+2 \mathrm{~b}=\left(\mathrm{y}-\mathrm{y}^{*}\right)-\frac{2-2 \gamma}{2-\gamma} \mathrm{s}-\frac{1-\beta}{\beta} 2 b_{H 0} \mathrm{~s}
$$

Combining the long run solution (68) with the Euler relations and the real exchange rate, we write the net foreign asset position as a function of short run consumption and the exchange rate:

$$
2 \mathrm{~b}=\frac{2-2 \gamma}{2-\gamma} \frac{2 \lambda-\gamma}{2-\gamma} \frac{\beta}{1-\beta}\left(\mathrm{c}-\mathrm{c}^{*}\right)-\frac{2-2 \gamma}{2-\gamma} \frac{2 \lambda-\gamma}{2-\gamma} \frac{\beta}{1-\beta} \frac{\gamma}{2-\gamma} \mathrm{s}+2 b_{H 0} \mathrm{~s}
$$

Substituting this in the short run current account leads to a relation between the exchange rate and consumption:

$$
\begin{aligned}
& \frac{2-2 \gamma}{2-\gamma}\left[1+\frac{2 \lambda-\gamma}{2-\gamma} \frac{\beta}{1-\beta}\right]\left(\mathrm{c}-\mathrm{c}^{*}\right) \\
& +\frac{2-2 \gamma}{2-\gamma}\left[\frac{2-2 \gamma}{2-\gamma}-\frac{2 \lambda-\gamma}{2-\gamma}\left[1+\frac{\beta}{1-\beta} \frac{\gamma}{2-\gamma}\right]\right] \mathrm{s} \\
= & -\frac{1}{\beta} 2 b_{H 0} \mathrm{~s}
\end{aligned}
$$

Combining with the short run money demand leads to the solution of for the 
exchange rate and the short run consumption differential:

$$
\begin{aligned}
& \mathrm{c}-\mathrm{c}^{*}=D^{-1}\left[\begin{array}{c}
\gamma \beta(1-\beta)\left[2-\gamma-\gamma \lambda+\frac{\beta}{1-\beta} \frac{2-2 \gamma}{2-\gamma}(2 \lambda-\gamma)\right] \\
+(2-\gamma)^{2}(1-\beta)\left[\beta(\lambda-1)-2 b_{H 0}\right]
\end{array}\right]\left(\overline{\mathrm{m}}-\overline{\mathrm{m}}^{*}\right)
\end{aligned}
$$

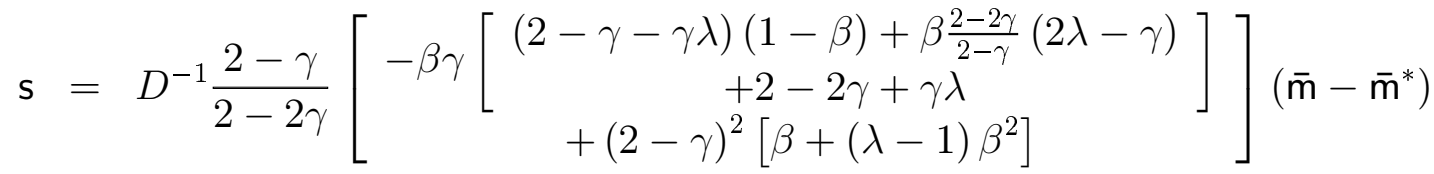

where:

$$
D=-\beta \gamma[2-2 \gamma+\gamma \lambda]+(2-\gamma)^{2}\left[\beta \lambda-2 b_{H 0}(1-\beta)\right]
$$

From the current accounts relations (61)-(62), the stock of net claims, b, is independent of $b_{H 0}$ :

$$
2 \mathrm{~b}=\mathrm{ca}=\frac{4-4 \gamma}{(2-\gamma)^{2}}(\lambda-1) \beta\left(\overline{\mathrm{m}}-\overline{\mathrm{m}}^{*}\right)
$$

The value of net foreign asset holdings (66) is affected by the exchange rate:

$$
\text { napf }=2\left(\mathrm{~b}-b_{H 0} \mathrm{~s}\right)
$$

We write the welfare effect by using (27)-(28):

$$
\mathrm{u}_{t}-\mathrm{u}_{t}^{*}=\left[\left(\mathrm{c}-\mathrm{c}^{*}\right)-\frac{\theta-1}{\theta}\left(\mathrm{y}-\mathrm{y}^{*}\right)\right]+\frac{\beta}{1-\beta}\left[\left(\overline{\mathrm{c}}-\overline{\mathrm{c}}^{*}\right)-\frac{\theta-1}{\theta}\left(\overline{\mathrm{y}}-\overline{\mathrm{y}}^{*}\right)\right]
$$

Combining this with the current accounts (61)-(62) in the short and the long run we write:

$$
\begin{aligned}
\mathbf{u}_{t}-\mathbf{u}_{t}^{*}= & -\frac{1}{\beta} 2 b_{H 0} \mathbf{s}+\frac{\lambda-\theta}{\lambda \theta}\left[\left(\mathrm{y}-\mathrm{y}^{*}\right)+\frac{\beta}{1-\beta}\left(\overline{\mathrm{y}}-\overline{\mathrm{y}}^{*}\right)\right] \\
& +\frac{\gamma}{2-\gamma}\left[\frac{1}{\lambda}\left(\mathrm{c}-\mathrm{c}^{*}\right)+\frac{2-2 \gamma}{2-\gamma} \mathbf{s}+\frac{\beta}{1-\beta}\left[\frac{1}{\lambda}\left(\overline{\mathrm{c}}-\overline{\mathrm{c}}^{*}\right)-\frac{2-2 \gamma}{2-\gamma}\left(\overline{\mathrm{w}}-\overline{\mathbf{w}}^{*}-\mathrm{s}\right)\right]\right]
\end{aligned}
$$




\subsubsection{The PPP case}

If all goods are traded $(\gamma=0)$, PPP holds at all horizons. When goods prices are flexible, we obtain:

$$
\begin{aligned}
\mathrm{s}_{t} & =\frac{\beta \lambda}{\beta \lambda-2 b_{H 0}(1-\beta)}\left(\overline{\mathrm{m}}-\overline{\mathrm{m}}^{*}\right) \\
\mathrm{c}_{t}-\mathrm{c}_{t}^{*} & =-\frac{2 b_{H 0}(1-\beta)}{\beta \lambda-2 b_{H 0}(1-\beta)}\left(\overline{\mathrm{m}}-\overline{\mathrm{m}}^{*}\right) \\
\mathrm{u}_{t}-\mathrm{u}_{t}^{*} & =-\left[1+\frac{\theta-1}{\theta} \lambda\right] \frac{2 b_{H 0}}{\beta \lambda-2 b_{H 0}(1-\beta)}\left(\overline{\mathrm{m}}-\overline{\mathrm{m}}^{*}\right)
\end{aligned}
$$

When goods prices are preset, relative consumption is the same in that short and the long run as the real exchange rate is always zero. The exchange rate and relative consumption are:

$$
\begin{aligned}
\mathrm{c}-\mathrm{c}^{*} & =(1-\beta) \frac{\beta(\lambda-1)-2 b_{H 0}}{\beta \lambda-2 b_{H 0}(1-\beta)}\left(\overline{\mathrm{m}}-\overline{\mathrm{m}}^{*}\right) \\
\mathrm{s} & =\frac{\beta+(\lambda-1) \beta^{2}}{\beta \lambda-2 b_{H 0}(1-\beta)}\left(\overline{\mathrm{m}}-\overline{\mathrm{m}}^{*}\right)
\end{aligned}
$$

The welfare differential is written as:

$$
\begin{aligned}
\mathrm{u}_{t}-\mathrm{u}_{t}^{*} & =-\frac{1}{\beta} 2 b_{H 0} \mathrm{~s}+\frac{\lambda-\theta}{\lambda \theta}\left[\left(\mathrm{y}-\mathrm{y}^{*}\right)+\frac{\beta}{1-\beta}\left(\overline{\mathrm{y}}-\overline{\mathrm{y}}^{*}\right)\right] \\
& =-\frac{1}{\beta} 2 b_{H 0} \mathrm{~s}+\frac{\lambda-\theta}{\theta} \beta \frac{1+2 b_{H 0}}{\beta \lambda-2 b_{H 0}(1-\beta)}\left(\overline{\mathrm{m}}-\overline{\mathrm{m}}^{*}\right)
\end{aligned}
$$


Table 1: U.S. Net International Investment Position, 1996-2003 (\$ billions)

\begin{tabular}{|l|c|c|c|c|}
\cline { 2 - 5 } \multicolumn{1}{l|}{ Annualized changes } & $1996-1999$ & $1999-2001$ & $2001-2002$ & $2002-2003$ \\
\hline Total & -229 & -631 & -245 & -98 \\
\hline Financial Flows & -178 & -447 & -570 & -546 \\
Security prices & -2 & -20 & 81 & 50 \\
Exchange rate & -49 & -164 & 244 & 398 \\
\hline
\end{tabular}

\begin{tabular}{|l|l|l|l|l|}
\hline Dollar appreciation $(\%$ & 2 & 7 & -7 & -14 \\
\hline
\end{tabular}


Table 2: Currency composition of U.S. assets and liabilities

end 2003, $\$$ billions

\begin{tabular}{|l|cccccc|c|}
\multicolumn{1}{c|}{} & Assets \\
\cline { 2 - 8 } \multicolumn{1}{c|}{} & Official & FDI & Equity & Debt & Banks & Other & Total \\
\hline Total & 268.3 & $2,730.3$ & $1,972.2$ & 502.1 & $1,776.3$ & 614.7 & $7,864.0$ \\
\hline US \$ & 190.6 & 14.8 & 11.4 & 333.7 & $1,671.9$ & 490.5 & $2,712.8$ \\
Non-US \$ & 77.8 & $2,715.5$ & $1,960.8$ & 168.5 & 104.4 & 124.2 & $5,151.1$ \\
\hline Euro & 21.9 & 817.8 & 564.5 & 90.1 & & & $1,494.3$ \\
U.K. pound & & 422.8 & 433.7 & 16.4 & & & 872.9 \\
Japanese yen & 17.6 & 112.1 & 208.8 & 25.1 & & & 363.6 \\
Canadian dollar & & 293.7 & 109.6 & 21.5 & & & 424.7 \\
Swiss franc & & 132.0 & 92.5 & 0.1 & & & 224.6 \\
Latin American curr. & & 203.7 & 63.2 & 0.5 & & & 267.4 \\
Caribbean curr. & & 238.7 & 208.5 & 0.2 & & & 447.5 \\
M-East and African curr. & & 57.8 & 29.3 & 1.0 & & & 88.1 \\
Other European curr. & & 100.9 & 58.8 & 8.2 & & & 168.0 \\
Other Asian curr. & & 335.9 & 191.6 & 5.3 & & & \\
Other & 38.2 & & 0.2 & & 104.4 & 124.2 & 267.0 \\
\hline
\end{tabular}

Share to total

\begin{tabular}{|cc|}
\hline F-E-D & Total \\
\hline & \\
$6.9 \%$ & $34.5 \%$ \\
$93.1 \%$ & $65.5 \%$ \\
\hline $28.3 \%$ & $19.0 \%$ \\
$16.8 \%$ & $11.1 \%$ \\
$6.6 \%$ & $4.6 \%$ \\
$8.2 \%$ & $5.4 \%$ \\
$4.3 \%$ & $2.9 \%$ \\
$5.1 \%$ & $3.4 \%$ \\
$8.6 \%$ & $5.7 \%$ \\
$1.7 \%$ & $1.1 \%$ \\
$3.2 \%$ & $2.1 \%$ \\
$10.2 \%$ & $6.8 \%$ \\
& $3.4 \%$ \\
\hline
\end{tabular}

\begin{tabular}{|c|c|c|c|c|c|c|c|c|}
\hline & \multicolumn{8}{|c|}{ Liabilities } \\
\hline & Official & FDI & Equity & Debt & Treasury & Banks & Other (1) & Total \\
\hline Total & $1,474.2$ & $2,435.5$ & $1,538.1$ & $1,853.0$ & 542.5 & $1,887.2$ & 784.5 & $10,515.0$ \\
\hline US \$ & $1,474.2$ & $2,435.5$ & $1,538.1$ & $1,442.5$ & 542.5 & $1,825.7$ & 722.0 & $9,980.5$ \\
\hline Non-US \$ & & & & 410.5 & & 61.5 & 62.4 & 534.4 \\
\hline Euro & & & & 247.6 & & & & 247.6 \\
\hline U.K. pound & & & & 66.9 & & & & 66.9 \\
\hline Japanese yen & & & & 64.0 & & & & 64.0 \\
\hline Canadian dollar & & & & 1.5 & & & & 1.5 \\
\hline Swiss franc & & & & 19.0 & & & & 19.0 \\
\hline Latin American curr. & & & & & & & & \\
\hline $\begin{array}{l}\text { Caribbean curr. } \\
\text { M-East and African curr }\end{array}$ & & & & & & & & \\
\hline Other European curr. & & & & & & & & \\
\hline Other Asian curr. & & & & 2.9 & & & & 2.9 \\
\hline Other & & & & 8.6 & & 61.5 & 62.4 & 132.5 \\
\hline
\end{tabular}

Share to total

\begin{tabular}{|cc|}
\hline F-E-D & Total \\
\hline $93.6 \%$ & $94.9 \%$ \\
$6.4 \%$ & $5.1 \%$ \\
\hline $3.9 \%$ & $2.4 \%$ \\
$1.1 \%$ & $0.6 \%$ \\
$1.0 \%$ & $0.6 \%$ \\
& \\
& \\
& \\
& \\
& \\
& \\
& \\
&
\end{tabular}

(1): includes U.S. currency held abroad 
Table 3: Currency composition of U.S. NIIP end 2003

\begin{tabular}{|l|c|c|c|}
\cline { 2 - 3 } \multicolumn{1}{c|}{} & \$ billions & $\begin{array}{c}\text { Percent } \\
\text { of GDP }\end{array}$ & $\begin{array}{c}\text { Percent of foreign } \\
\text { currency net assets }\end{array}$ \\
\hline Total & $-2,651.0$ & $-24.1 \%$ & \multicolumn{1}{|c|}{} \\
\hline US \$ & $-7,267.7$ & $-66.1 \%$ & \\
Non-US \$ & $4,616.7$ & $42.0 \%$ & $27.0 \%$ \\
\hline Euro & $1,246.7$ & $11.3 \%$ & $17.5 \%$ \\
U.K. pound & 806.0 & $7.3 \%$ & $6.5 \%$ \\
Japanese yen & 299.6 & $2.7 \%$ & $9.2 \%$ \\
Canadian dollar & 423.2 & $3.9 \%$ & $4.5 \%$ \\
Swiss franc & 205.7 & $1.9 \%$ & $5.8 \%$ \\
Latin American curr. & 267.4 & $2.4 \%$ & $9.7 \%$ \\
Caribbean curr. & 447.5 & $4.1 \%$ & $1.9 \%$ \\
M-East and African curr. & 88.1 & $0.8 \%$ & $3.6 \%$ \\
Other European curr. & 168.0 & $1.5 \%$ & $11.5 \%$ \\
Other Asian curr. & 529.9 & $4.8 \%$ & $2.9 \%$ \\
Other & 134.5 & $1.2 \%$ & \\
\hline
\end{tabular}




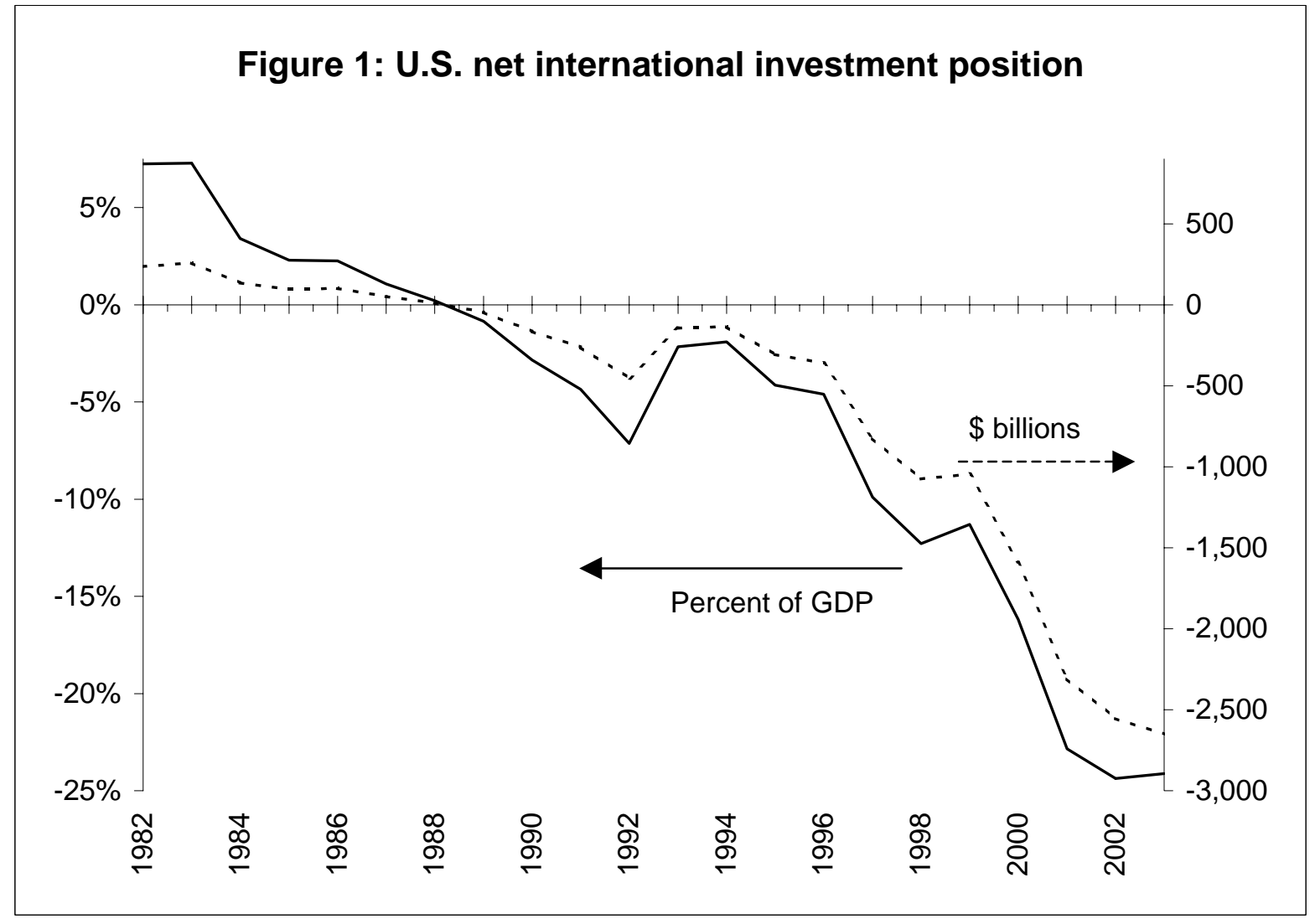

Figure 2: Valuation effect of the exchange rate

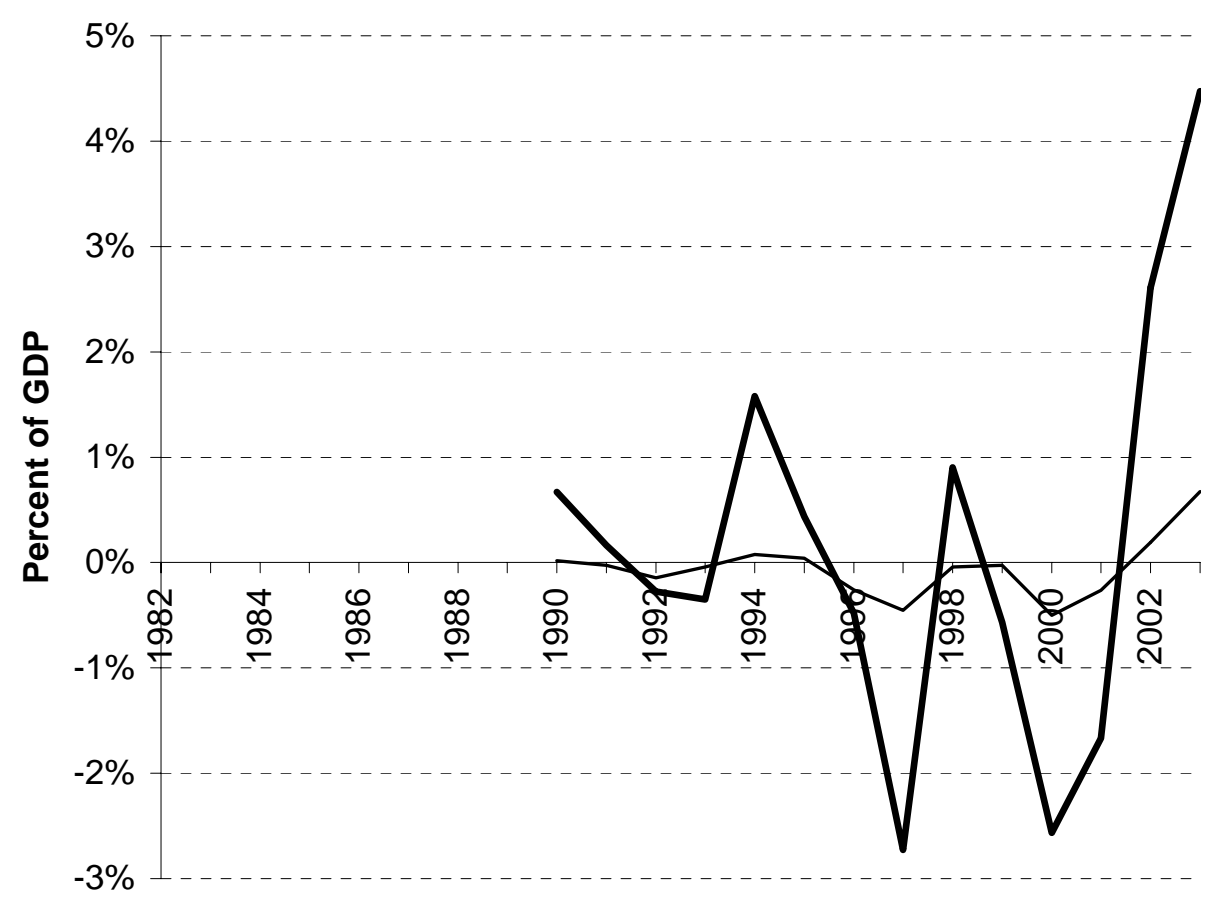




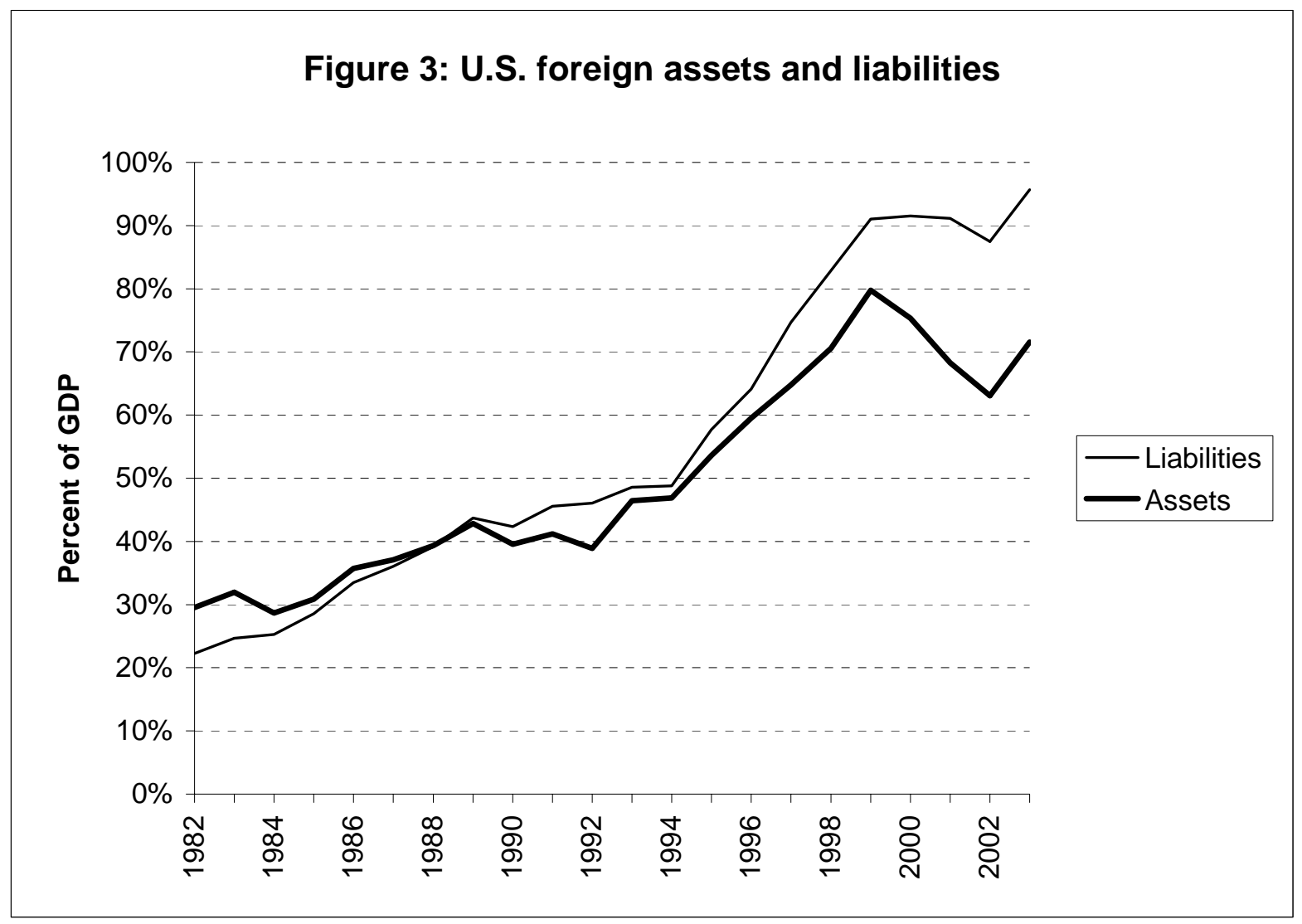

Figure 4: Share in U.S. foreign currency NIIP and U.S. exports (2003)

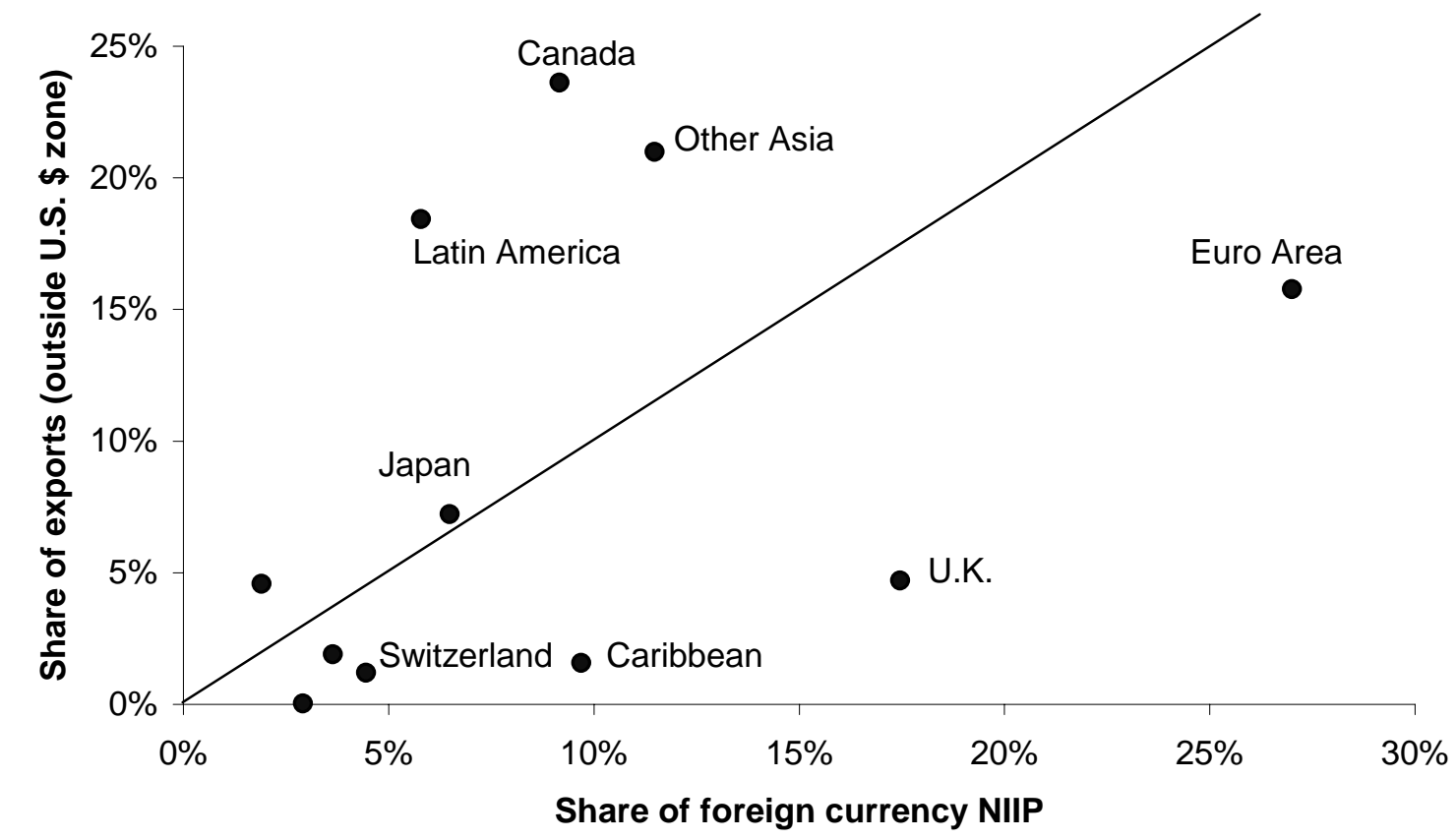


Figure 5: Exchange rate and relative consumption

$$
\mathrm{m}=1, \gamma=0
$$

$$
\longrightarrow: \lambda=1,-: \lambda=\theta=6
$$

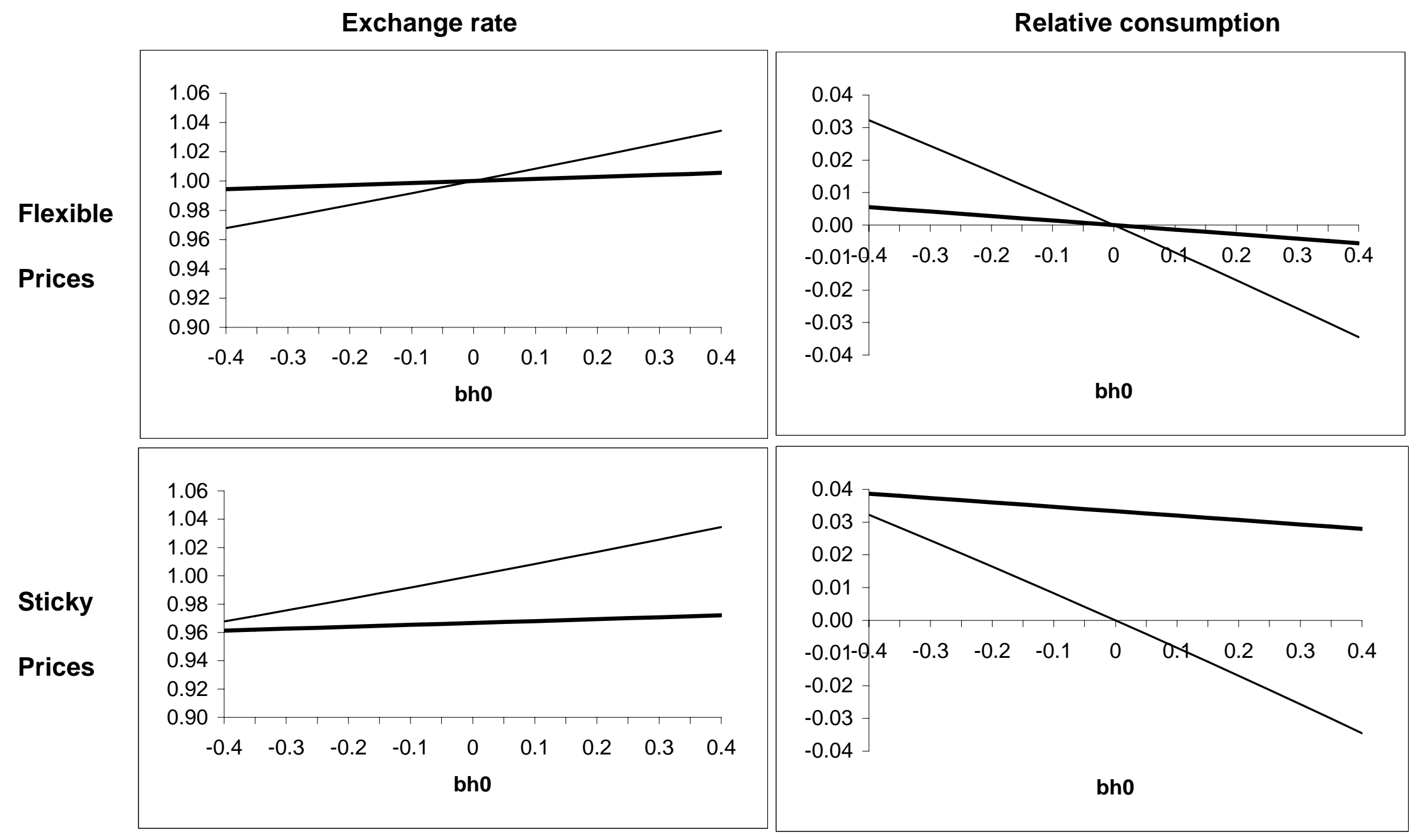




\section{Figure 6: Welfare \\ $\mathrm{m}=1, \gamma=0$}

High substitutability between home and foreign goods: $\lambda=\theta=6$

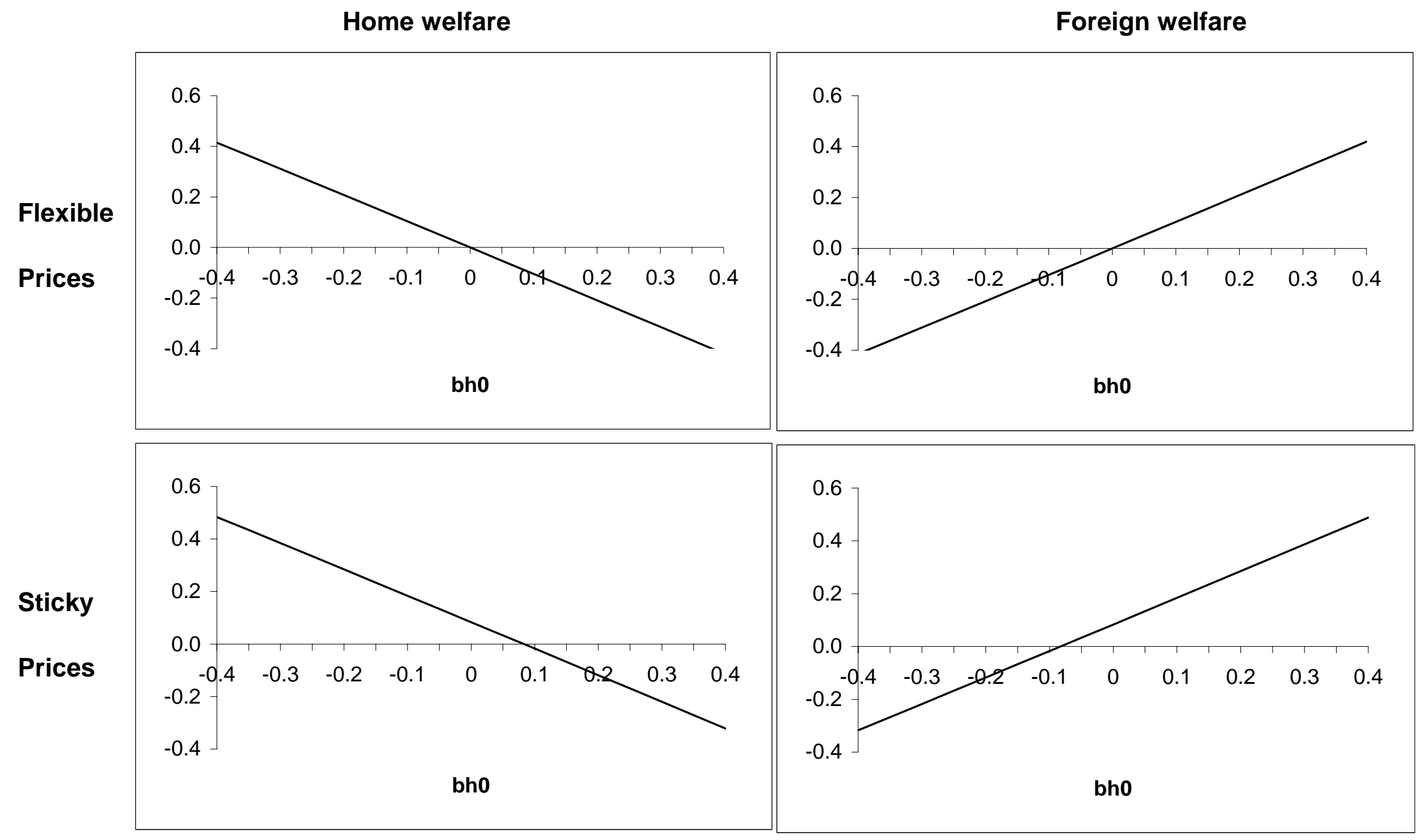




\section{Figure 7: Welfare \\ $\mathrm{m}=1, \gamma=0$}

Low substitutability between home and foreign goods: $\lambda=1$

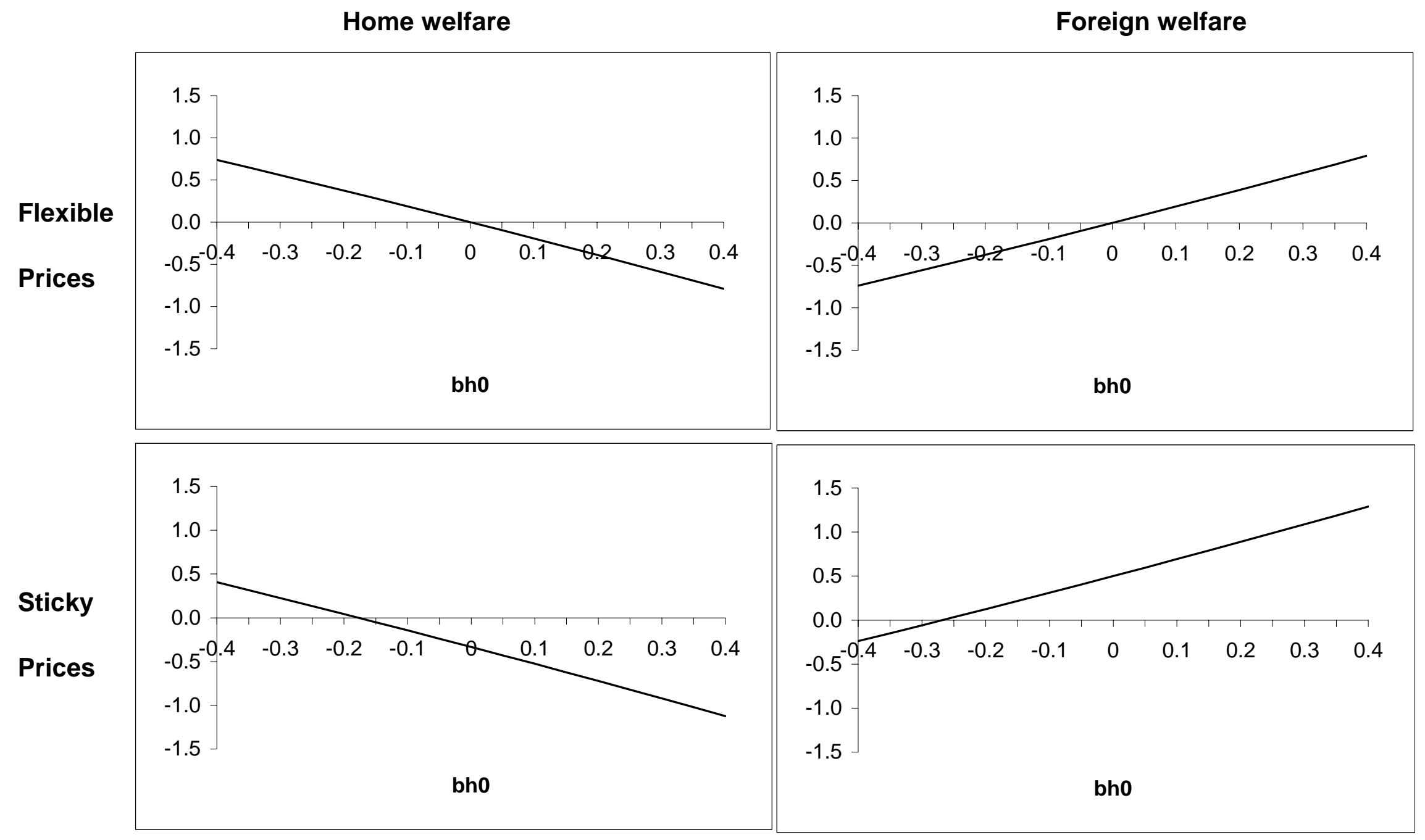


Figure 8: Welfare under non-traded goods

$m=1, \lambda=6$

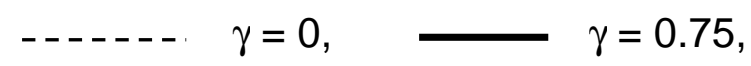
$\gamma=0.95$

Home welfare

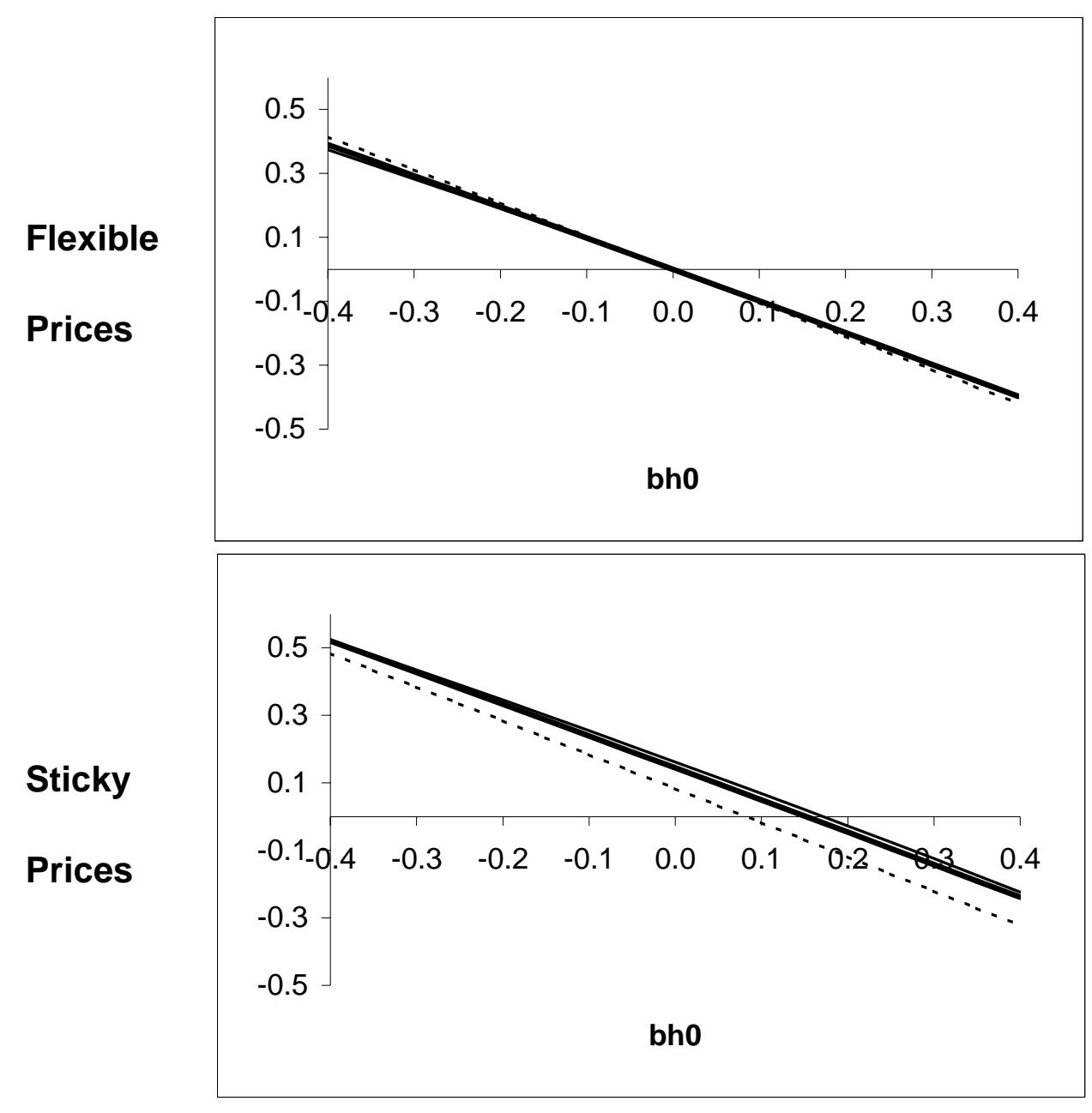

Foreign welfare

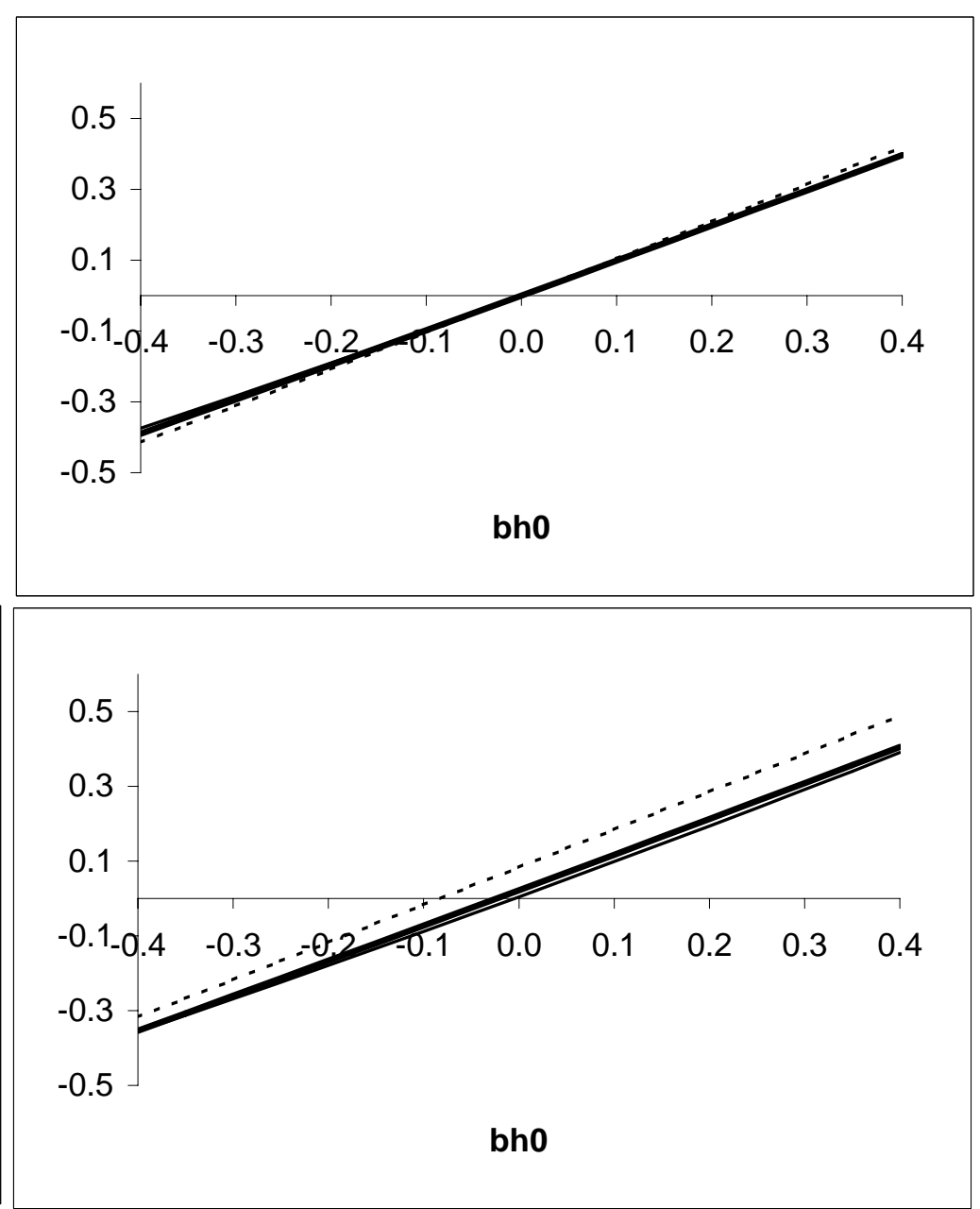

